\title{
How We Manage Myelofibrosis Candidates for Allogeneic Stem Cell Transplantation
}

\author{
Nicola Polverelli ${ }^{1, *} \mathbb{D}^{\circ}$, Mirko Farina $^{1}{ }^{(}$, , Mariella D'Adda ${ }^{2}$, Enrico Damiani ${ }^{3}$, Luigi Grazioli ${ }^{4}$, Alessandro Leoni ${ }^{1}$, \\ Michele Malagola ${ }^{1} \mathbb{(}$, Simona Bernardi ${ }^{1,5}{ }^{\circledR}$ and Domenico Russo ${ }^{1}$
}

1 Unit of Blood Diseases and Bone Marrow Transplantation, Cell Therapies and Hematology Research Program, Department of Clinical and Experimental Sciences, University of Brescia, ASST Spedali Civili di Brescia, P.le Spedali Civili 1, 25123 Brescia, BS, Italy; mirkfar@gmail.com (M.F.); alessandro.leoni@unibs.it (A.L.); michele.malagola@unibs.it (M.M.); simona.bernardi@unibs.it (S.B.); domenico.russo@unibs.it (D.R.)

2 Hematology Division, Department of Oncology, ASST Spedali Civili di Brescia, P.le Spedali Civili 1, 25123 Brescia, BS, Italy; marielladadda@libero.it

3 2nd Division of General Surgery, Department of Medical \& Surgical Sciences, ASST Spedali Civili di Brescia, P.le Spedali Civili 1, 25123 Brescia, BS, Italy; enricoandreadamiani@libero.it

4 Department of Radiology, ASST Spedali Civili di Brescia, P.le Spedali Civili 1, 25123 Brescia, BS, Italy; luigi.grazioli@asst-spedalicivili.it

5 CREA Laboratory (Centro di Ricerca Emato-Oncologica AIL), ASST Spedali Civili di Brescia, P.le Spedali Civili 1, 25123 Brescia, BS, Italy

* Correspondence: nicola.polverelli@unibs.it; Tel.: +39-(0)30-399-6811; Fax: +39-(0)30-399-6021

check for updates

Citation: Polverelli, N.; Farina, M.; D'Adda, M.; Damiani, E.; Grazioli, L.; Leoni, A.; Malagola, M.; Bernardi, S.; Russo, D. How We Manage

Myelofibrosis Candidates for Allogeneic Stem Cell Transplantation. Cells 2022, 11, 553. https://doi.org/ 10.3390/cells11030553

Academic Editors: Marco Vitale and Elena Masselli

Received: 25 December 2021

Accepted: 3 February 2022

Published: 5 February 2022

Publisher's Note: MDPI stays neutral with regard to jurisdictional claims in published maps and institutional affiliations.

Copyright: (c) 2022 by the authors. Licensee MDPI, Basel, Switzerland. This article is an open access article distributed under the terms and conditions of the Creative Commons Attribution (CC BY) license (https:// creativecommons.org/licenses/by/ $4.0 /)$.

\begin{abstract}
Moving from indication to transplantation is a critical process in myelofibrosis. Most of guidelines specifically focus on either myelofibrosis disease or transplant procedure, and, currently, no distinct indication for the management of MF candidates to transplant is available. Nevertheless, this period of time is crucial for the transplant outcome because engraftment, non-relapse mortality, and relapse incidence are greatly dependent upon the pre-transplant management. Based on these premises, in this review, we will go through the path of identification of the MF patients suitable for a transplant, by using disease-specific prognostic scores, and the evaluation of eligibility for a transplant, based on performance, comorbidity, and other combined tools. Then, we will focus on the process of donor and conditioning regimens' choice. The pre-transplant management of splenomegaly and constitutional symptoms, cytopenias, iron overload and transplant timing will be comprehensively discussed. The principal aim of this review is, therefore, to give a practical guidance for managing MF patients who are potential candidates for allo-HCT.
\end{abstract}

Keywords: myelofibrosis; allogeneic stem cell transplantation; bone marrow transplantation; ruxolitinib; splenectomy; JAK-inhibitors; iron overload; deferasirox

\section{Introduction}

Allogeneic hematopoietic stem cell transplantation (allo-HCT) still represents the only curative option for patients with myelofibrosis (MF), a myeloproliferative neoplasm characterized by splenomegaly, constitutional symptoms, anemia, and a natural progression to acute leukemia [1]. The median age at diagnosis (roughly 60 years) of MF and the significant transplant-related morbidity and mortality limited, in the past, the use of allo-HCT only to a minority of patients. However, during the last few years, a series of advancements led to a change of this scenario. Novel and less toxic conditioning platforms, as well as a better HLA donor selection and GVHD and anti-infective therapies, greatly improved the feasibility and safety of allo-HCT. All these advances led to extending the indication for a transplant to a larger number of elderly patients affected by hematological neoplasms, including MF [2].

The increasing proportion of older allo-HCT candidates was recently confirmed in an Italian multicenter study that analyzed the GITMO allogeneic transplant activity in 
elderly individuals (>60 years) between 2000 and 2017. In that experience, the median age at transplant gradually raised over time, and more than $50 \%$ of all transplants were performed in the last 5-year period [3]. In parallel, the use of unrelated and mismatched related donors also increased, and transplant procedure was progressively extended to less fit patients, thanks to an increased use of reduced intensity conditioning regimens.

In addition to transplant procedures' improvements, JAK-inhibitors have significantly ameliorated the clinical conditions of MF patients, thus allowing to consider allo-HCT in an increasing number of individuals [4-8]. Accordingly, the number of transplant procedures for MF steadily increased over time, as confirmed by several reports of the European Society for Blood and Marrow Transplantation (EBMT). Specifically, in a Europe-wide analysis including 4142 patients submitted to transplant for MF between 1995 and 2018 across 278 Centers, only 389 patients were transplanted before 2006; conversely, 1695 patients belonged to the earlier transplant era (2015-2018) [9]. The numbers of transplant procedures exponentially rose after 2012, when treatment with ruxolitinib was widely available in Europe. Whether the adoption of JAK-inhibitors utilized prior to transplant have improved the outcomes remains matter of debate and points out the importance of the pre-transplant management of MF patients. In other words, the availability of effective medical treatments and better transplant outcomes raises the need for a proper patient selection and management.

The MF transplant indication, the judgement of patient eligibility for a transplant, the choice of donor/stem cell source, and conditioning, as well as the clinical management of MF patients waiting for a transplant, will be addressed in the present review. The aim is to give a practical guide for dealing with the process from allo-HCT indication to transplantation in MF.

\section{Transplant Indication}

Clinical prognostic scoring systems play a pivotal role for guiding selection of MF patient who may benefit from allo-HCT. The most frequently used scores are: (1) the International Prognostic Scoring System (IPSS) [10], which estimates survival at the time of MF diagnosis; (2) the Dynamic IPSS (DIPSS) [11], utilizing the same five factors of IPSS, but applicable at any stage during the disease course; (3) and the DIPSS-plus, which considers three additional adverse factors (transfusion dependency, thrombocytopenia $<100 \times 10^{9} / \mathrm{L}$, and unfavorable cytogenetics) $[12,13]$.

Currently, the European LeukemiaNet/EBMT expert consensus, published in 2015, proposed that patients with intermediate-2- or high-risk disease according to the IPSS, DIPSS, or DIPSS-plus and age $<70$ years should be considered potential candidates for allo-HCT [14]. Conversely, the indications for transplantation for intermediate-1-risk patients is still debated [15]. The aforementioned consensus suggested that patients with intermediate-1-risk disease and age $<65$ years should be considered as candidates if they present with either transfusion-dependent anemia, or a significant percentage of peripheral blasts $(>2 \%)$, or adverse (as defined by the DIPSS-plus classification) cytogenetics [14]. These recommendations were released in the light of a previous study that reported the comparative effect of a transplant versus a non-transplant approach across several European and American Hematological Centers. By merging the original DIPSS dataset with $255 \mathrm{MF}$ patients treated with conventional therapy and a cohort of 188 transplanted MF subjects, the authors found a net benefit for transplantation only among intermediate- 2 or high risk DIPSS patients. Regarding intermediate-1 DIPSS patients, survival curves did not significantly differ in the two groups [15]. Similar results were confirmed in a recent CIBMTR analysis [16]. Herein, a survival advantage was seen for the transplant in the DIPSS intermediate 1 group; however, this improvement was apparent only one year after transplant, due to a worse NRM in the peri-transplant period. Taken together, these data seem to further confirm the validity of ELN/EBMT 2015 indications, where intermediate 1 DIPSS patients should receive individual counseling. 
However, such scores have been proven to poorly predict patients' outcome for patients with secondary myelofibrosis (sMF; post-Polycythemia Vera (PPV-MF) or postEssential Thrombocythemia myelofibrosis (PET-MF)), as they present a better survival compared to primary myelofibrosis $[17,18]$. For those patients with sMF, the so-called Myelofibrosis SECondary to PV and ET-Prognostic Model (MYSEC-PM) was developed and documented better prognostic ability $[19,20]$. In addition, its superior predictive role was confirmed in the allo-HCT setting in $159 \mathrm{sMF}$ allo-HCT patients [21].

Subsequently, several somatic mutations have been found in patients with $\mathrm{MF}$, and some of them have been shown to have an impact on survival (OS) and on the risk of disease progression and blastic transformation [22-24]. Triple negative patients (e.g., lacking of a detectable JAK2, CALR, or MPL mutation) present a poor outcome (median survival of 3.2 years), as well as high molecular risk patients, which are conventionally defined by the presence of at least one of the EZH2, ASXL1, IDH1/2, and SRSF2 mutations, and who are associated with both worse overall and leukemia-free survival [25]. In addition, U2AF1Q157 mutation was recently confirmed as a detrimental risk factor for disease progression and survival [26]. Considering the poor outcome of these patients, some authors questioned whether earlier transplantation should be considered for those who have 'triple negative' disease or high molecular risk profile, even if they belong to lower risk classes according to standard prognostic scores [27]. Actually, a study on behalf MPD research consortium documented that allo-HCT was able to overcome the prognostic value of several of these mutations in a cohort of 101 patients, supporting the value of early transplantation in such a high-risk population [28].

In order to integrate the modern molecular information, the mutation-enhanced IPSS "MIPSS70" and "MIPSS70-plus" (including cytogenetics) scoring systems have been developed as decisional tools for transplant indication in patients less than 70 years old. Significant risk factors for overall survival were leukocyte count $>25 \times 10^{9} / \mathrm{L}$, platelet count $<100 \times 10^{9} / \mathrm{L}$, presence of high molecular risk mutations, hemoglobin $<100 \mathrm{~g} / \mathrm{L}$, peripheral blood blasts $\geq 2 \%$, constitutional symptoms, high molecular risk category, fibrosis grade $>2$, and absence of CALR type-1-like mutations and adverse cytogenetics (the latter in MIPSS70-plus only). Recent updates to 'MIPSS70-plus version 2' occurred with the recognition of U2AF1Q157 and new sex- and severity-adjusted hemoglobin thresholds [29]. Importantly, these scores incorporate current molecular data and up-to-date WHO 2016 disease classification and can aid decisions regarding allo-HCT. Finally, a genetically inspired prognostic score system (GIPSS) exclusively based on genetic markers is available [30].

Taking into account the large number of available prognostic tools, a question arises: What to use?

Currently, it is unclear which score is more accurate in defining the indication for a transplant, particularly when a patient falls into categories with markedly different survival expectations [31]. In daily practice, for example, often, a patient with MF may present different IPSS and MIPSS-70 scores with significant difference in OS. This kind of discrepancy between risk models may occur in up to $50 \%$ of patients with sMF [20], resulting in significative challenges in transplant indication. The use of MYSEC-PM seems to be more accurate in sMF prognostication, while, in primary MF, no clear evidence of superior efficacy between different prognostic scores is demonstrated in the allo-HCT setting; therefore, each Center should follow its institutional policy (e.g., unavailability of extended molecular analysis, medullary punctio sicca with failed cytogenetics). Table 1 summarizes the available prognostic scores, highlighting those categories of patients with shorter survival, suitable for transplantation. 
Table 1. List of the available risk score for MF and their prognostic relevance. PMF: Primary Myelofibrosis; sMF: Secondary Myelofibrosis; HMR: high molecular risk; Int: intermediate; TD transfusion-dependent; BM: bone marrow; OS: overall survival.

\begin{tabular}{|c|c|c|c|c|c|c|c|c|}
\hline \multicolumn{2}{|c|}{ Risk Score } & IPSS & DIPSS & DIPSS-Plus & MYSEC-PM & MIPSS70 & MIPSS70-Plus v2.0 & GIPSS \\
\hline \multicolumn{2}{|c|}{ Applicability } & $\begin{array}{c}\text { PMF } \\
\text { at diagnosis }\end{array}$ & $\begin{array}{l}\text { PMF } \\
\text { at any time }\end{array}$ & $\begin{array}{l}\text { PMF } \\
\text { at any time }\end{array}$ & $\begin{array}{c}\text { sMF } \\
\text { at diagnosis }\end{array}$ & $\begin{array}{l}\text { PMF } \\
\text { at any time }\end{array}$ & $\begin{array}{l}\text { PMF } \\
\text { at any time }\end{array}$ & $\begin{array}{l}\text { PMF } \\
\text { at any time }\end{array}$ \\
\hline \multicolumn{2}{|c|}{ Features } & Clinical & Clinical & $\begin{array}{l}\text { Clinical \& } \\
\text { Molecular }\end{array}$ & $\begin{array}{l}\text { Clinical \& } \\
\text { molecular }\end{array}$ & $\begin{array}{l}\text { Clinical \& } \\
\text { molecular }\end{array}$ & $\begin{array}{l}\text { Clinical \& } \\
\text { molecular }\end{array}$ & Genetical only \\
\hline \multirow{10}{*}{ Items (points) } & Age & $>65 \mathrm{y}(1)$ & $>65 \mathrm{y}(1)$ & $>65 \mathrm{y}(1)$ & Age $(0.15 / y)$ & - & - & - \\
\hline & Leucocytes & $>25 \times 10^{9} / \mathrm{L}(1)$ & $>25 \times 10^{9} / \mathrm{L}(1)$ & $>25 \times 10^{9} / \mathrm{L}(1)$ & - & $>25 \times 10^{9} / \mathrm{L}(1)$ & - & - \\
\hline & Blasts & $\geq 1 \%(1)$ & $\geq 1 \%(1)$ & $\geq 1 \%$ (1) & $\geq 3 \%(2)$ & $\geq 2 \%(2)$ & $\geq 2 \%(2)$ & - \\
\hline & $\begin{array}{l}\text { Constitutional } \\
\text { symptoms }\end{array}$ & Yes/No (1) & Yes/No (1) & Yes/No (1) & Yes/No (1) & Yes/No (1) & Yes/No (2) & - \\
\hline & Hemoglobin & $<10 \mathrm{~g} / \mathrm{dL}(1)$ & $<10 \mathrm{~g} / \mathrm{dL}(2)$ & $<10 \mathrm{~g} / \mathrm{dL}(2)$ & $<11 \mathrm{~g} / \mathrm{dL}(2)$ & $<10 \mathrm{~g} / \mathrm{dL}(1)$ & $\begin{array}{l}<8 \mathrm{~g} / \mathrm{dL}(\mathrm{F}) /<9 \mathrm{~g} / \mathrm{dL} \\
(\mathrm{M})(2) \\
8-9.9 \mathrm{~g} / \mathrm{dL}(\mathrm{F}) / 9-10.9 \\
\mathrm{~g} / \mathrm{dL}(\mathrm{M})(1)\end{array}$ & - \\
\hline & TD-anemia & - & - & Yes/No (1) & - & - & - & - \\
\hline & Cytogenetics & - & - & Unfavorable $^{£}(1)$ & - & - & $\begin{array}{l}\text { very high risk }{ }^{\S}(4) \\
\text { unfavorable }{ }^{\S}(3)\end{array}$ & $\begin{array}{l}\text { very high risk } \S(2) \\
\text { unfavorable } \S(1)\end{array}$ \\
\hline & Platelets & - & - & $<100 \times 10^{9} / \mathrm{L}(1)$ & $<150 \times 10^{9} / \mathrm{L}(2)$ & $<100 \times 10^{9} / \mathrm{L}(2)$ & - & - \\
\hline & Molecular & - & - & - & No CALR (2) & $\begin{array}{l}\text { No CALR type-1 (1) } \\
\text { HMR } \% \text { mutation (1) } \\
>1 \mathrm{HMR}^{\%} \\
\text { mutations (2) }\end{array}$ & $\begin{array}{l}\text { No CALR type-1 (2) } \\
\mathrm{HMR}^{\$} \text { mutation (2) } \\
>1 \mathrm{HMR}^{\$} \text { mutations (3) }\end{array}$ & $\begin{array}{l}\text { No CALR type-1 (1) } \\
\text { ASXL1 (1) } \\
\text { SRSF2 (1) } \\
\text { U2AF1Q (1) }\end{array}$ \\
\hline & BM fibrosis & - & - & - & - & Grade $\geq 2$ (1) & - & - \\
\hline \multicolumn{2}{|c|}{$\begin{array}{l}\text { Higher risk Categories (score) } \\
\text { Median OS }\end{array}$} & $\begin{array}{c}\text { Int-2 (2): } 4 \text { y } \\
\text { High }(3-4): 2.3 y\end{array}$ & $\begin{array}{c}\text { Int-2 (3-4): } 4 \text { y } \\
\text { High }(5-6): 1.5 y\end{array}$ & $\begin{array}{l}\text { Int-2 (2-3): } 2.9 \mathrm{y} \\
\text { High (4-6): } 1.3 \mathrm{y}\end{array}$ & $\begin{array}{c}\text { Int-2 }(>14<16): 4.4 \mathrm{y} \\
\text { High }(\geq 16): 2 \mathrm{y}\end{array}$ & $\begin{array}{c}\text { Int (2-4): } 7.1 \mathrm{y} \\
\text { High }(>4): 2.3 \mathrm{y}\end{array}$ & $\begin{array}{c}\text { High (5-8): } 4.1 \mathrm{y} \\
\text { Very high }(\geq 9): 1.8 \mathrm{y}\end{array}$ & $\begin{array}{l}\text { Int-2 (2): } 4.2 \mathrm{y} \\
\operatorname{High}(\geq 3): 2 \mathrm{y}\end{array}$ \\
\hline
\end{tabular}

${ }^{£}$ Unfavorable karyotype: complex karyotype or single or two abnormalities, including $+8,-7 / 7 \mathrm{q}-, \mathrm{i}(17 \mathrm{q}),-5 / 5 \mathrm{q}-, 12 \mathrm{p}-$, inv(3), or 11q23 rearrangement. $\%$ HMR mutations according to MIPSS70: ASXL1, SRSF2, EZH2, IDH1, IDH2. \$ HMR mutations according to MIPSS70-plus v2.0: ASXL1, SRSF2, EZH2, IDH1, IDH2, and U2AF1Q157. § Very unfavorable karyotype: single/multiple abnormalities of $-7, \mathrm{i}(17 \mathrm{q})$, inv(3)/3q21, 12p- $/ 12 \mathrm{p} 11.2,11 \mathrm{q}-/ 11 \mathrm{q} 23$, or other autosomal trisomies, not including $+8 /+9$ (e.g., $+21,+19)$; Favorable: normal karyotype or sole abnormalities of $13 \mathrm{q}-,+9,20 \mathrm{q}-$, chromosome 1 translocation/duplication or sex chromosome abnormality, including -Y; 'Unfavorable': all other abnormalities. 


\section{Patient Selection}

Once defining the indication for a transplant, the evaluation of patients' eligibility for allo-HCT is crucial for the selection of appropriate candidates for such an intensive procedure. In fact, non-relapse mortality represents one of the major limits for transplant success, particularly in MF. The selection of MF patients may represent a crucial point. Currently, we have several tools useful for the evaluation of patients' eligibility to transplant. However, only a minority of them has been specifically tested in MF cohorts of patients, and further information is warranted.

One of the easiest tools for the evaluation of patients' eligibility for a transplant is represented by Karnofsky performance status (KPS). On the basis of a simple scale from 0 (death) to 100 (normality), according to subject well-being, KPS has been invariably associated with transplant outcomes, including myeloablative and reduced intensity conditioning platforms. Patients with scores lower than 90 are generally projected to a worse transplant result, due to increased non-relapse mortality [32].

Then, comorbidity has been extensively considered in the past in order to properly select eligible candidates for a transplant. Probably, the most used tool for patients' evaluation and selection is represented by the hematopoietic cell transplantation-specific comorbidity index (HCT-CI). Developed by Sorror et al. and published in 2005, this score includes the presence and severity of 15 comorbidities. HCT-CI classifies patients at low (0), intermediate (1-2), and high $(\geq 3)$ risk, correlating with worse survival due to increased non-relapse mortality [33]. HCT-CI comorbidity score was developed and validated on cohorts of relatively young patients (median age $<50$ years) [34,35]. In addition, this score has not been extensively studied in MF; therefore, we actually do not know whether it can represent an effective tool for the selection of MF allo-HCT candidates. In fact, some reports have highlighted some peculiar aspects of elderly candidates for a transplant, as usually MF allo-HCT patients are.

In this regard, as observed in other hematological diseases, the median age at transplantation progressively increased, as well as numbers of MF transplant procedures, over time [9]. In the early 2000s, only a small proportion of patients were submitted for a transplant after 60 years; later on, the dramatic advances in transplant procedure led to consider transplant in older adults, even up to 75 years. The utility of transplant over 70 years is questioned by several transplant physicians due to concerns related to NRM and effective survival benefit in such a population. Recently, a joint study from the Spanish MF registry and Chronic Malignancies Working Party of the EBMT addressed the role of transplant in MF patients over 65 years [36]. The authors reported, once again, a survival benefit for the transplant after the first year from the procedure; importantly, increasing a recipient's age did not correlate with worse outcome, thus supporting the idea to consider transplant also in more advanced age groups, at least up to 75 years. For this category of patients, it is necessary to perform a comprehensive evaluation taking into account physiological and geriatric components. Several experiences documented the complexity of evaluating elderly fitness in onco-hematology [37]. In addition, some reports showed a poor predictive value of the original HCT-CI and suggested the implementation of geriatric components for improving patients' stratification [38]. Recently, we published an experience on 228 elderly (>60 years) allo-HCT patients, including 18 patients with MF. In this cohort, a multidimensional geriatric assessment (FIL score) was found to highly predict NRM and, therefore, allo-HCT outcome. Thus, this tool might be set to become a new instrument for the selection of elderly candidates for a transplant, including MF patients [39]. Several other multidimensional scores are currently under investigation, and important information is awaited in the near future.

Finally, by combining disease-, patient-, and donor-specific features, a Myelofibrosisspecific Transplant Scoring System (MTSS) has been proposed [40]. On the basis of the following clinical and molecular variables (leukocytes $>25 \times 10^{9} / \mathrm{L}$, platelets $<150 \times 10^{9} / \mathrm{L}$, Karnofsky scale $<90 \%$, age $>57$ years, ASXL1 mutation (1 point each), JAK2-mutated or triple negative status ( 2 points), and mismatched unrelated donor ( 2 points)), patients are 
stratified in 4 different groups: low (score 0-2), intermediate (score 3-4), high (score 5), and very high (score $>5$ ), with a post-transplant 5-year survival estimation of $90 \%, 77 \%, 50 \%$, and $34 \%$, respectively. The performance of this score was found to be higher compared to all the other available tools.

In the effort to implement all disease- and transplant-specific scores, all MF patients up to 75 years with high risk disease (as defined as life expectancy lower than 5 years according to standard MF-oriented prognostic scores) should be considered possible candidates for a transplant. For those patients at low-intermediate-risk MTSS with no significant contraindications, transplant should be pursued as soon as possible; on the contrary, other treatment options should be evaluated in very high risk-risk MTSS category or with severe comorbidities. In a high MTSS risk group of patients, where a 5-year NRM of 36\% after transplant is expected, allo-HCT procedure should be chosen on a case-by-case basis taking into account patient preference and other possibly relevant factors (comorbidities, cognitive status, geriatric assessment).

\section{Donor Choice and Stem Cell Source}

Donor source plays a crucial role in MF-patients transplanted outcome. Indeed, the use of HLA-mismatched unrelated donors have been reported to be an independent risk factor for both disease-free and overall survival in several reports [41-43]. On the other hand, there is a general consensus that, as for other diseases, an HLA-matched donor, either sibling or unrelated, is associated with a better outcome $[40,44]$, although few authors claim that MF patients transplanted from an unrelated donor, regardless of HLA-matching status, present a worse survival [43].

Recently, alternative donors have been used, showing proof of their role in MF transplant [45-47]. The use of cord blood was reported only for a minority of patients. One of the major limitations for use of this source of stem cells is represented by a scarce number of stem cells, leading to increased risk of graft failure and higher NRM. In fact, previous experiences showed a remarkable $40 \%$ of engraftment failure among MF patients receiving cord blood transplant [48]. At the moment, in the opinion of the authors, this type of transplant still remains experimental in MF. Conversely, haploidentical donors have been increasingly employed over time. Evidence is increasing in favor of this option that seems to offer similar results compared to HLA-matched donors also in MF setting [45].

Taking into account stem cells source, there is no consensus on the preferred source of stem cells (bone marrow versus peripheral-derived stem cells), although PBSC seems to guarantee a faster recovery $[47,49]$. In addition, higher stem cells doses $\left(>7 \times 10^{6} \mathrm{CD} 34+\right.$ cells $\left./ \mathrm{Kg}\right)$ can lead to a faster engraftment and superior survival, particularly in a sibling setting, as recently demonstrated [50,51].

In summary, when considering allo-HCT in MF, sibling donors and high stem cells doses should be considered as the best options. Matched-unrelated or haploidentical donors might be a second preferred choice.

Beside HLA-compatibility and stem cell source other parameters could be considered: donor age and gender, female parity, AB0 compatibility, and CMV serostatus combination represent other important points for discussion when more than one donor is available [52].

\section{Conditioning Regimen}

Unfortunately, there are limited data on the optimal conditioning regimen because of the lack of prospective clinical trials comparing myeloablative (MAC) to reduce insensitivity conditioning (RIC) regimens in MF. Patients' comorbidity and functional status can significatively influence the choice of conditioning regimen. Indeed, retrospective studies in the pre-ruxolitinib era indicate that MAC should be preferred in young patients without comorbidities and with an HLA-matched sibling donor, while RIC may be preferred in patients older than 50 years [14].

MAC regimens potentially have a good rate of survival, ranging from 47 to $61 \%$ of OS at 5 years from transplant $[53,54]$. Usually, the conditioning regimen was based on busulfan 
plus cyclophosphamide and total body irradiation with or without cyclophosphamide, but transplant related mortality (NRM) and GvHD rates were high, especially in older individuals, ranging from 20 to $48 \%$ at 1 year. RIC has been increasingly used in MF in consideration of the older age of MF allo-HCT candidates.

Historically, the first prospective EBMT multicenter phase II trial of RIC consisted of busulfan $\left(10 \mathrm{mg} / \mathrm{kg}\right.$ ) orally (or equivalent IV dose) plus fludarabine $\left(180 \mathrm{mg} / \mathrm{m}^{2}\right)$ (FLU-BU) and in vivo T-cell depletion with anti-thymocyte globulin. This protocol resulted in low rates of primary graft failure and rapid hematologic recovery [41]. Another commonly used RIC regimen is based on Fludarabine $90 \mathrm{mg} / \mathrm{m}^{2}$, combined with melphalan $140 \mathrm{mg} / \mathrm{m}^{2}$ (FLU-MEL); this protocol has been compared in a retrospective study with the BU-FLU regimen, showing an increased early toxicity and NRM, but better disease control with superimposable long-term outcomes [55]. Subsequently, a randomized GITMO study comparing fludarabine in combination with busulfan $10 \mathrm{mg} / \mathrm{kg}$ i.v. or thiotepa $12 \mathrm{mg} / \mathrm{kg}$ failed to identify significant differences in terms of clinical outcome [56].

It is evident that a direct comparison of RIC and MAC regimens is extremely difficult. A large retrospective analysis of the EBMT including 2224 patients with MF, stratified according to conditioning intensity, showed no statistically significant difference in terms of engraftment, GvHD, NRM, and overall survival, while there was a trend toward a higher relapse rate in patients receiving the RIC regimen [57].

In recent years, the scientific community has shown an increasing interest in the use of double-alkylating conditioning regimen thiotepa-busulfan-fludarabine (TBF). Based on some retrospective studies, such a regimen has been documented to favorably affect transplant outcome, thanks to a faster donor engraftment and better disease control [58-61]. Prospective and randomized trials are warranted to confirm these preliminary results and to give conclusive information on the preferred conditioning regimen.

Taken together, these results support the current EBMT/ELN consensus guidelines that suggest to tailor the conditioning regimen intensity on the basis of a patient's fitness and disease status $[14,62]$.

\section{Splenomegaly Management}

Splenomegaly is a frequent finding in MF. More than $80 \%$ of MF patients present splenomegaly at diagnosis, and, in a significant proportion of cases, the spleen has a considerable size, with around a quarter of patients presenting a spleen palpable more than $16 \mathrm{~cm}$ below left costal margin [11,63,64]. Biological and clinical studies support the pivotal role of spleen in MF disease maintenance and progression [65-67]. In addition, previous reports documented that spleen size and splenectomy before allo-HCT could affect engraftment and possibly survival $[54,68]$. In a recent European multicenter study reporting 546 patients with available information on spleen size at the time of transplant, patients undergoing a transplant with a spleen palpable below $5 \mathrm{~cm}$ from left costal margin presented the best transplant outcome compared to patients with a spleen between 5 and 14 and more than $15 \mathrm{~cm}$, respectively. The increasing risk of death was found to be related to non-relapse mortality, with patients belonging to the lower category presenting a significantly shorter time to engraftment [69]. This report confirmed a prior observation by Bacigalupo et al., who reported a higher NRM in patients with splenomegaly diameter $>22 \mathrm{~cm}$ by ultrascan evaluation [70].

It is, therefore, crucial to pay particular attention to splenomegaly management before transplant.

In the next paragraphs, we will discuss about treatment options for MF patients with significant splenomegaly.

\subsection{Medical Options (JAK Inhibitors)}

The availability of JAK inhibitors has changed the treatment paradigm of MF patients. Based on the efficacy in reducing constitutional symptoms and splenomegaly, ruxolitinib 
has become the first treatment option for patients complaining of disease-related manifestations [71-74].

Better patients' conditions and spleen shrinking are expected to have a positive influence on allo-HCT, too. In addition, improvement of pro-inflammatory status typical of MF may favor a positive graft function [75], thus decreasing the risk of graft failure and poor graft function, a life-threatening complication frequently occurring after transplant in MF patients $[62,76]$.

In 2016, Shanavas first reported on a quite large cohort of 100 allo-HCT MF patients with prior exposure to JAK-inhibitors ( $90 \%$ ruxolitinib-treated). Around one quarter of patients achieved a clinical improvement while on the treatment, and their transplant outcome was significantly better as compared to either non-responsive or progressive patients. As expected, the inferior survival in patients with blast-phase MF was due to higher relapse risk in this cohort; conversely, a better NRM was observed in JAKi-responsive compared to non-responsive patients [44]. Subsequently, Kroger et al. led a multicenter retrospective analysis on behalf of EBMT, collecting a cohort of 551 patients, of whom 277 received ruxolitinib prior to allo-HCT between 2012 and 2016. RUX-responsive patients presented a faster engraftment and lower risk of relapse with consequent better event-free survival, defined as the time from allo-HCT until relapse, disease progression, or death, whichever occurred first [77]. According to spleen size, those patients achieving a spleen reduction over $5 \mathrm{~cm}$ below left costal margin on ruxolitinib seemed to have the better outcome, suggesting to titrate ruxolitinib to the maximum tolerated dose in the effort to reach the lowest spleen size as possible at the time of allo-HCT [69].

All these data support the pre-transplant use of ruxolitinib, even though drug-suspension strategy is still not well-defined. Preliminary data from the literature confirmed the safety of ruxolitinib therapy prior allogeneic steam cell transplant (allo-HCT), although some unexpected side effects were recorded when ruxolitinib was abruptly discontinued [44,78-80]. The cytokines rebound after ruxolitinib withdrawal may have induced some cases of cardiac shock and tumor lysis syndrome recorded in those experiences [81]. These reports have induced researchers to extend the use of ruxolitinib to the conditioning regimen phase, or even until engraftment [82-84]. All the studies showed favorable transplant outcomes, with particularly reduced risk for GVHD, indirectly confirming the results of multicenter phase III REACH trials $[85,86]$, where ruxolitinib also has proven activity in treating GVHD. Table 2 summarizes the available studies that have investigated the role of ruxolitinib prior to or peri-transplantation. 
Table 2. List of studies investigating the role of ruxolitinib (RUX) in the pre- or peri-transplant period.

\begin{tabular}{|c|c|c|c|c|c|c|c|c|c|c|c|c|}
\hline Author & Year & $\mathbf{N}$ & $\begin{array}{l}\text { Study } \\
\text { Design }\end{array}$ & $\begin{array}{c}\text { Conditioning } \\
\text { Regimens }\end{array}$ & $\begin{array}{l}\text { RUX } \\
\text { Use }\end{array}$ & $\begin{array}{c}\text { Spleen } \\
\text { Response }\end{array}$ & $\begin{array}{c}\text { RUX Tapering } \\
\text { Strategy }\end{array}$ & $\begin{array}{c}\text { Discontinuation } \\
\text { Syndrome }\end{array}$ & GF (\%) & $\begin{array}{c}\text { G2-4 } \\
\text { aGVHD (\%) }\end{array}$ & NRM (\%) & OS (\%) \\
\hline Jaekel, N. [78] & 2014 & 14 & Retro & $\begin{array}{l}\text { RIC (Flu-Bu/TBI) } \\
\text { MAC (NA) }\end{array}$ & Pre & $64 \%$ & $\begin{array}{c}\text { Stop at } \\
\text { conditioning }\end{array}$ & None & $7 \%$ & $14 \%$ & $7 \%$ at $9 \mathrm{~m}$ & $50 \%$ at $1 \mathrm{y}$ \\
\hline Stübig, T. [79] & 2014 & 22 & Retro & RIC (Flu-Bu/Mel/Treo) & Pre & $\begin{array}{l}45 \%(>50 \%) \\
24 \%(<50 \%)\end{array}$ & $\begin{array}{c}\text { Stop at } \\
\text { conditioning }\end{array}$ & None & $0 \%$ & $36 \%$ & $14 \%$ at $1 \mathrm{~m}$ & $81 \%$ at $1 \mathrm{y}$ \\
\hline Shanavas, M. [44] & 2016 & 100 & Retro & $\begin{array}{c}\text { RIC } \\
\text { (Flu- } \\
\mathrm{Bu} / \mathrm{Mel} / \mathrm{Cy} / \mathrm{BCNU} / \mathrm{TBI}) \\
\mathrm{MAC} \\
(\mathrm{Flu}-\mathrm{Bu} / \mathrm{Mel} \text { or Bu-Cy) }\end{array}$ & Pre & $23 \%$ & Not defined & $10 \%$ & $8 \%$ & $37 \%$ & $28 \%$ at $2 y$ & $61 \%$ at $2 y$ \\
\hline Kroger, N. [84] & 2018 & 12 & Prosp & RIC (Flu-Bu) & Peri & $100 \%$ & $\begin{array}{l}\text { Stop at day }+28 \\
\text { post-transplant }\end{array}$ & None & $0 \%$ & $8 \%$ & $0 \%$ at $17 \mathrm{~m}$ & $100 \%$ at $17 \mathrm{~m}$ \\
\hline Kadir, S.S.S.A. [87] & 2018 & 46 & Retro & $\begin{array}{c}\text { RIC (Flu-Bu/ } \\
\text { FLAMSA-Flu-Bu) }\end{array}$ & Pre & $39 \%$ & Not defined & None & $4 \%$ & $37 \%$ & $23 \%$ at $2 y$ & $73 \%$ at $2 \mathrm{y}$ \\
\hline Gupta, V. [88] & 2019 & 21 & Prosp & RIC (Flu-Bu) & Pre & $45 \%$ & $\begin{array}{c}\text { Tapering off } \\
\text { at conditioning } \\
\text { (4 days before) }\end{array}$ & None & $16 \%$ & $47 \%$ & $28 \%$ at $2 y$ & $66 \%$ at $2 y$ \\
\hline Salit, R.B. [82] & 2020 & 28 & Prosp & $\begin{array}{c}\text { RIC (Flu-Mel) } \\
\text { MAC (Bu-Cy } \pm \text { Flu) }\end{array}$ & Pre & NA & $\begin{array}{c}\text { During } \\
\text { Conditioning } \\
\text { (day-4) }\end{array}$ & None & $0 \%$ & $78 \%$ & $7 \%$ at $13 \mathrm{~m}$ & $86 \%$ at $2 y$ \\
\hline Ali, H. [89] & 2021 & 18 & Prosp & RIC (Flu-Mel) & Peri & NA & $\begin{array}{c}\text { Day }+30 \\
\text { post-transplant }\end{array}$ & None & $0 \%$ & $17 \%$ & $23 \%$ at $1 \mathrm{y}$ & $77 \%$ at $1 \mathrm{y}$ \\
\hline Kroger, N. [77] & 2021 & 277 & Retro & $\begin{array}{c}\text { RIC (NA) } \\
\text { MAC (NA) }\end{array}$ & Pre & $56 \%$ & Not defined & $6 \%$ & NR & $29 \%$ & $\begin{array}{c}26 \% \text { NR at } 1 y \\
15 \% \text { R at } 1 y\end{array}$ & $66 \%$ at $2 y$ \\
\hline Robin, M. [90] & 2021 & 59 & Prosp & RIC (Flu-Mel) & Pre & $46 \%$ & Variable & $15.8 \%$ & $3 \%$ & $66 \%$ & $42 \%$ at $1 \mathrm{y}$ & $68 \%$ at $1 \mathrm{y}$ \\
\hline
\end{tabular}

Retro: retrospective; Prosp: prospective; NA: not available; Flu: fludarabine; Bu: Busulfan; TBI: total body irradiation; Cy: cyclophosphamide; MAC: myeloablative conditioning; RIC: Retro: retrospective; Prosp: prospective; NA: not available; Flu: fludarabine; Bu: Busulfan; TBI: total body irradiation; Cy: cyclophosphamited intensity conditioning; GF: graft failure; aGVHD: acute graft versus host disease; NRM: non-relapse mortality; OS: overall survival; NR: no response; R: response.
reduced 
When ruxolitinib fails, second generation JAK-inhibitors can be considered. Recently, fedratinib has received FDA and EMA approval for its use in this setting [91,92].

In the JAKARTA-2 trial including MF patients with prior exposure to ruxolitinib, around $30 \%$ of subjects obtained a spleen response ( $\geq 35 \%$ spleen volume decreases at 6-month evaluation) and/or symptom response [93]. Side effects included hematology, gastrointestinal effect, and deficit in thiamine blood concentration, manageable with supportive treatments (prokinetics and anti-diarrheal drugs plus thiamine supplement).

Momelotinib and pacritinib are other possible options with interesting effectiveness spectrum. Momelotinib showed mild efficacy in spleen reduction after ruxolitinib exposure; however, a significant reduction of transfusion-independency $(41 \%)$ was observed in phase III SIMPLIFY-2 trial [94]. Pacritinib documented efficacy (20-30\% in spleen volume reduction and/or symptoms response) in the subset of patients with low-platelet counts $\left(<100 \times 10^{9} / \mathrm{L}\right)$, a somewhat neglected category of patients [95].

Novel classes of drugs (e.g., BH3-mimetics, CDK-6-inhibitors, BET-inhibitors, telomerasesinhibitors, and others), alone or in combination with JAK-inhibitors, have proven initial efficacy in MF, with relevant biological effects (reduction of BM fibrosis, molecular burden decrease) in a significant proportion of patients [96]. Unfortunately, almost all ongoing studies exclude transplant candidates; therefore, their safety and efficacy in this setting needs to be fully explored.

\subsection{Splenectomy}

The role of splenectomy in MF prior to transplant has been under debate for decades. Several reports showed a shorter time to engraftment after splenectomy $[54,68,70,97]$; however, until 2021, no clear benefit was demonstrated on overall survival. Moreover, a prospective EBMT trial, evaluating Fludarabine-Busulfan plus ATG reduced intensity conditioning regimen reported an increase in relapse risk after transplant in splenectomized patients [41].

However, some biological and clinical information support the potential benefit of splenectomy. From the biological point of view, it is known that MF spleens carry additional molecular and cytogenetical abnormalities compared to peripheral blood; leukemic evolution inside spleen has also been described [65-67]. Therefore, spleen removal is expected to have a disease-modifying effect.

From the clinical point of view, surgery is expected to ameliorate thrombocytopenia, portal hypertension, anemia, and spleen-related symptoms in a significant proportion of patients [98]. These effects may be translated in a reduced risk for graft failure and improved graft function; on the other side, a better pre-transplant performance status could lead to improved non-relapse mortality.

Based on these premises, a retrospective study including $1195 \mathrm{MF}$ allo-HCT patients was conducted with the aim to give a conclusive answer to the question whether to perform splenectomy before transplantation could affect long term transplant outcome. In that experience, $202(17 \%)$ patients were submitted to splenectomy prior to transplant. As expected, the proportion of surgical procedures tended to decrease over time, probably thanks to the availability of novel treatments (e.g., ruxolitinib). Splenectomy was confirmed to be associated to a faster neutrophil and platelet recovery and lower non-relapse mortality with an increased relapse risk.

However, in patients with progressive disease, splenectomy prior to transplant was found to have a positive effect. In fact, splenectomized patients had a $54 \%$ decrease in death risk compared to subjects with progressive splenomegaly over $15 \mathrm{~cm}$ below left costal margin. In this context, the excess of relapse was not evident [69].

Certainly, splenectomy in MF is burdened by a significant morbidity and mortality: thrombo-hemorrhagic events and infections are frequent. Overall, around $1 / 3$ of MF patients undergoing surgery will experience a perioperative complication, and mortality is reported in about $5-10 \%$ of cases. Bleeding and thrombosis are prominent, and roughly $10-15 \%$ of patients can experience such complications [98]. Among the recognized risk factors for vascular events, 
spleen mass, leukocytosis, and thrombocytopenia play a significant role. In those patients with thrombocytosis and or leukocytosis, cytoreductive treatment might prevent thrombohemorrhagic complications and should be taken into account. Early mobilization and use of anti-coagulant can be also useful.

In addition, anti-infective prophylaxis is mandatory. Post-splenectomy infections are frequent, with around $10 \%$ of subjects experiencing this complication; overwhelming post-splenectomy infection (OPSI), often associated to encapsulated bacteria, is a serious concern. Vaccination before splenectomy is, therefore, a mainstay. Pneumococcal, meningococcal, and H.influenzae vaccinations are highly recommended before splenectomy, ideally $>2$ weeks before a planned splenectomy. In adults, no clear evidence supports the routine use of antibiotics as primary prophylaxis; however, in some selected high-risk cases (patients with infectious history, etc.), penicillin or alternatives can be given [99].

Furthermore, a higher risk of leukemic transformation has been reported, by propensity score analysis, in an Italian multicenter retrospective study. In that experience, a higher than two-fold increase in blast evolution was observed among splenectomized subjects [100]. It should be noted, however, that prognostically-relevant cytogenetical and molecular analyses were not available at that time. Therefore, caution is needed in data interpretation. For this concern, it should be considered to proceed early to transplantation after splenectomy, ideally within 1-3 months, if feasible.

Can all these complications preclude or delay allo-HCT? With the aim to answer this relevant question, a French nationwide study was conducted [101]. In this trial, all MF patients undergoing unrelated donor search in the French national registry during the period 2008-2016 were recruited. Patients who had received splenectomy before registration in French registry were excluded. Patients were followed from the registration to death, splenectomy, lost to tracking, or the end of the study for at least 18 months. By applying a multistate model, the researchers documented that splenectomy was significantly associated with higher probability of transplant within 4 months after surgery. Importantly, no increase in death risk was observed after splenectomy and only few splenectomy-related complications were indicated as the leading cause of transplant preclusion.

The current evidence, therefore, suggests the use of splenectomy in all suitable patients with progressive splenomegaly, while on any medical treatment, palpable over $15 \mathrm{~cm}$ below left costal margin.

\subsection{Splenic Irradiation}

Splenic irradiation (SI) has been used in the past for splenomegaly-related symptoms in those patients with high surgical risk, particularly before the advent of JAK-inhibitors.

Radiation dosage widely varies among Centers, usually ranging from 100 to 1000 cGy in 5-10 fractions. The mechanism of action of radiation therapy on MF spleen is still fairly unknown. SI is thought to have a role in reducing the number of neoplastic cells into the spleen, leading to improvements in both splenic size and discomfort. Unfortunately, the benefit of splenic irradiation is usually short-lived, and worsening of cytopenias is frequently observed.

Overall, information on SI relies on small retrospective single-center experiences. In addition, scant information about the its role before transplant is available.

In the largest study available, reporting $23 \mathrm{MF}$ patients submitted to SI due to symptomatic splenomegaly, the response rate on splenomegaly was $93.9 \%$, with a median maximal decrease in spleen length of $5 \mathrm{~cm}$. Symptom relief was documented in $95.6 \%$ of patients; however, the benefit duration was limited to a median of 6 months. Significant cytopenias were recorded in around one half of the study cohort, with life-threatening events in $26 \%$ of patients [102].

The effects of splenic irradiation prior to transplant have been investigated in small case series, with proof of mild efficacy [103]. Currently, a multicenter study on behalf of Chronic Malignancies Working Party of EBMT is ongoing to elucidate the role for this procedure before or during allo-HCT. To date, splenic irradiation could be offered 
to those MF patients with massive splenomegaly and surgical contraindications only in experienced Centers.

\section{Management of Cytopenia before Transplant}

Another important issue to be managed before transplant is the presence of cytopenias. Indeed, cytopenias are frequent in patients with MF: significant anemia is recorded in around $1 / 3$ of patients at diagnosis, and its worsening with the requirement of red-blood cells support is one of the strongest predictors of survival [11,12]. Similarly, thrombocytopenia may be associated to increased risk of leukemic transformation [104]. MF-directed treatment, namely JAK-inhibitors, may worsen cytopenias itself due to on- and off-target mechanism of action; as a result, dose reduction or discontinuation is frequently required, leading to disease unresponsiveness or progression [7,105].

One of the most relevant effects of transfusion-dependency is represented by iron overload. Ineffective erythropoiesis may aggravate iron accumulation. A bulk of literature highlights the negative effect of iron for organs, such as liver, heart, joints, and endocrine organs. Hepato-cirrhosis, cardiomyopathy, and several endocrinologic disturbances, caused by increased production of reactive oxygen species, have been documented in long-lasting iron overload [106]. Iron overload may be even more important in allo-HCT recipients. The excess of iron may induce short and long-term complications [107]. Infectious risk from opportunistic agents (such as fungi and bacteria), acute and chronic GHVD, and sinusoidal obstruction syndrome are more frequently observed in such patients [108]. Importantly, iron overload may affect bone marrow microenvironment leading to a not-permissive habitat for hematopoietic stem cells with increased risk for graft failure and poor graft function, particularly fearsome in the MF setting [62,109-111]. In addition, a high number of pre-transplant blood units did correlate with unfavorable prognosis in an Italian study by Bacigalupo et al. [70].

Early intervention should be advisable, particularly in patients with a hemoglobin value lower than $10 \mathrm{~g} / \mathrm{dL}$. Available drugs for the management of anemia in MF include corticosteroids, androgens, danazol, immunomodulating agents (e.g., thalidomide, lenalidomide), and epoetins.

Single-agent corticosteroid (prednisone 0.5 to $1 \mathrm{mg} / \mathrm{Kg} /$ day) and androgen therapy (e.g., testosterone enanthate 400 to $600 \mathrm{mg}$ weekly, oral fluoxymesterone $10 \mathrm{mg}$ three times per day, or danazol at a dose of $600 \mathrm{mg}$ /day) have been used in MF cases, obtaining a response rate ranging from 30 to $40 \%$ [112-114]. Low dose thalidomide (50 mg/day) as single agent or in combination with corticosteroids (prednisone 15 to $30 \mathrm{mg} /$ day) and lenalidomide (5-10 $\mathrm{mg} / \mathrm{d})$, in the presence of $\operatorname{del}(5)(\mathrm{q} 31)$, showed a response rate of approximately $20 \%$ [115-117].

Immunomodulating agents have also been associated with responses on thrombocytopenia $[118,119]$.

Keeping in mind the possible side effects of these drugs, androgen preparations should be avoided in patients with prostate disease or concomitant liver disease, thalidomide and its analogs should be used with caution in patients with or at risk of thrombosis and neuropathy, and corticosteroids may significantly increase infectious risk or metabolic disturbances.

Response of anemia to epoetin treatment has been reported in 45-50\% of MF patients, mainly in the context of inadequate endogenous erythropoietin level $(<125 \mathrm{U} / \mathrm{L})$ and non-transfusion-dependent anemia: female sex, leukocyte count $\geq 10 \times 10^{9} / \mathrm{L}$, and serum ferritin < $200 \mathrm{ng} / \mathrm{mL}$ seem to confer a significantly higher probability of response to erythropoiesis-stimulating agents [120-122]. The efficacy of epoetin treatment was also documented among ruxolitinib-treated patients [123].

Finally, there are new promising agents under evaluation: the activin receptor ligand traps (e.g., luspatercept), currently approved for refractory anemia with ring sideroblasts (RARS-MDS); recombinant pentraxin-PRM-151 with anti-fibrotic activity; and new generation JAK-inhibitors (momelotinib, pacritinib), as discussed in the previous chapter. The 
present available data about these new drugs come mainly from phase II trials, and more information is required to understand their real clinical benefit in MF.

In those patients with transfusion-dependent anemia and iron overload, iron chelation therapy is the main pharmacological option for decreasing iron deposits, possibly reducing the risk of short- and long-term post-allo-HCT complications. While deferoxamine (shorthalf-life and prolonged infusion) and deferiprone (risk for agranulocytosis) have a minimal role in chelation of such patients, deferasirox, an oral iron-chelator, is increasingly used. This drug has proven its efficacy in reducing iron burden with manageable toxicity (mainly creatinine increase) in transfusion-dependent patients [124].

Its efficacy has been also confirmed in the MF context. Deferasirox is able to achieve a significant response in terms of chelation and anemia improvement, particularly when started early $[125,126]$. The use of deferasirox chelation therapy in the context of allo-HCT has been evaluated in several prospective and retrospective studies [107]. Unfortunately, none of those specifically focused on MF. The large majority reported favorable effect on chelation and transplant outcome. Taking into account the deleterious effect of iron toxicity on engraftment [127], it seems appropriate to limit iron overload prior to transplant in MF. Post-transplant chelation is another possible option, even though the concomitant use of nephrotoxic agents (calcineurin inhibitors, antivirals, etc.) may limit its feasibility, particularly in the peri-transplant period.

These data encourage the timely use of deferasirox in those patients with transfusiondependent anemia and signs of iron overload. Ideally, all patients receiving support with more than 10 units of blood and/or serum ferritin $>1000 \mathrm{ng} / \mathrm{mL}$ should receive irondirected treatment. Allo-HCT should be delivered as soon as possible to such patients in order to limit the number of transfusions and the excess of iron.

\section{Timing of Transplant}

Last, timing of transplant in MF is of paramount importance. The availability of novel and effective drugs has led many MF experts to consider a delay of transplant at the loss of response. Whether to proceed to transplant early or after treatment failure is a controversial area. At the same time, some data support the idea of not waiting for the transplant at the time of disease progression. The first item supporting this approach is that around $70 \%$ of MF patients receiving JAK inhibitors are expected to discontinue treatment at 5-year follow-up [128]. As described before, a progressive splenomegaly may induce a delayed engraftment and increased risk of non-relapse mortality after transplant [69]. Second, it is well recognized that JAK-inhibitors do not affect the risk of leukemic evolution [129]. For patients evolving in accelerated or blastic phase of MF, the prognosis is poorer. A 2 -fold increase in relapse incidence was found among patients submitted to transplant with accelerated phase of disease (blast cells 10-19\%) [130]. In the overt blast phase, the probability to achieve a long-term disease control after transplant is severely reduced, even in the context of a pre-transplant complete remission [131].

As a consequence, our approach is to proceed to the transplant as soon as possible, given the time of best disease response.

\section{Conclusions}

This critical review highlights the complexity and the importance of pre-transplant management of MF (Figure 1). Many small details can make a big difference in MF transplant outcome. As a consequence, a strict collaboration between MF and allo-HCT physicians should be pursued for laying the foundations of cures for MF patients. 


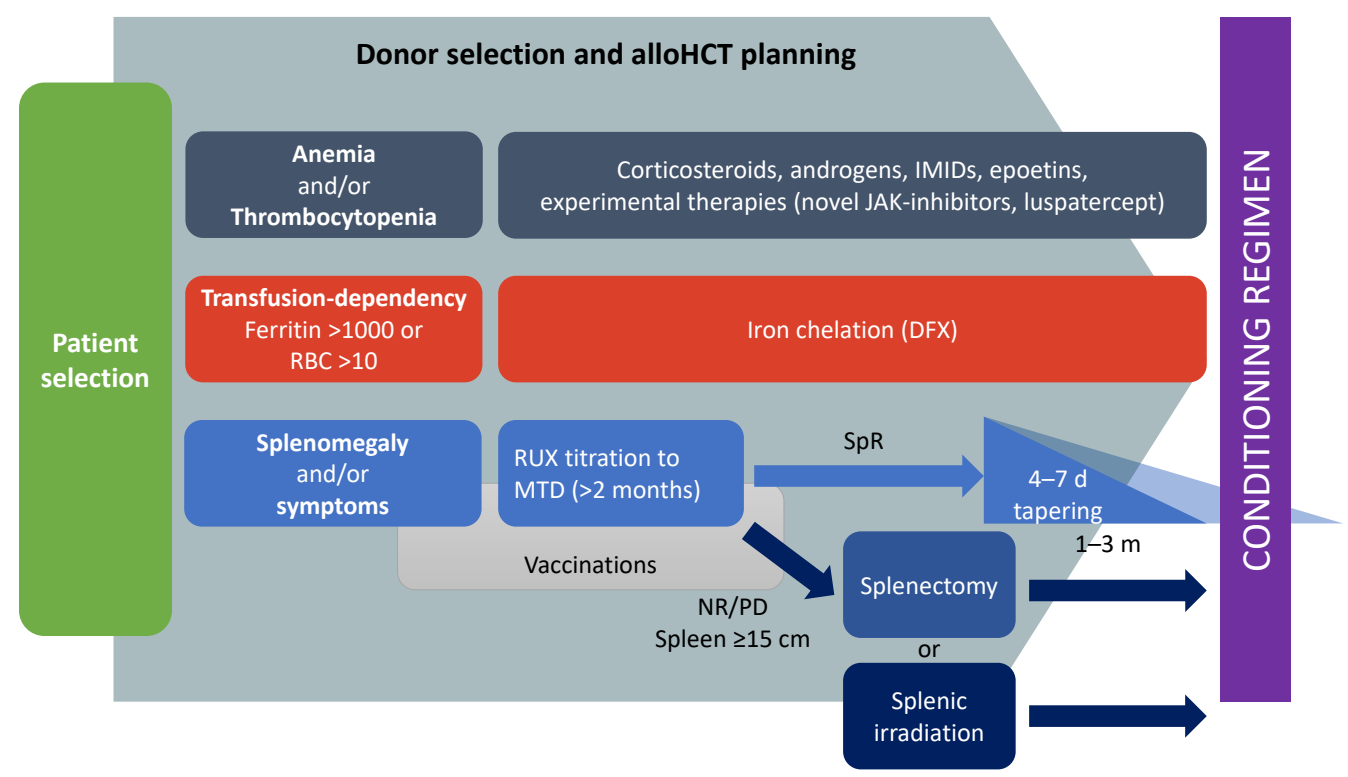

Figure 1. Proposed pre-transplant management of MF candidates to allogeneic stem cells transplantation. IMIDs: immunomodulating agents; RUX: ruxolitinib; MTD: maximum tolerated dose; RBC: red blood cells; SpR: spleen response; NR: no response; PD: progressive disease.

Author Contributions: Writing—original draft preparation, N.P.; writing—review and editing, N.P., M.F., M.D., E.D., L.G., A.L., M.M., S.B. and D.R. All authors have read and agreed to the published version of the manuscript.

Funding: This research received no external funding.

Institutional Review Board Statement: Not applicable.

Informed Consent Statement: Not applicable.

Data Availability Statement: Not applicable.

Conflicts of Interest: The authors declare no conflict of interest.

\section{References}

1. Arber, D.A.; Orazi, A.; Hasserjian, R.; Thiele, J.; Borowitz, M.J.; Le Beau, M.M.; Bloomfield, C.D.; Cazzola, M.; Vardiman, J.W. The 2016 revision to the World Health Organization classification of myeloid neoplasms and acute leukemia. Blood 2016, 127, 2391-2405. [CrossRef] [PubMed]

2. Morello, E.; Malagola, M.; Bernardi, S.; Pristipino, C.; Russo, D. The role of allogeneic hematopoietic stem cell transplantation in the four P medicine era. Blood Res. 2018, 53, 3-6. [CrossRef] [PubMed]

3. Malagola, M.; Polverelli, N.; Rubini, V.; Martino, M.; Patriarca, F.; Bruno, B.; Giaccone, L.; Grillo, G.; Bramanti, S.; Bernasconi, P.; et al. Gitmo registry study on allogeneic transplantation in patients aged over 60 from 2000 to 2017. Improvements and criticisms. Transplant. Cell Ther. 2021, 28, 96.e1-96.e11. [CrossRef]

4. Palandri, F.; Tiribelli, M.; Benevolo, G.; Tieghi, A.; Cavazzini, F.; Breccia, M.; Bergamaschi, M.; Sgherza, N.; Polverelli, N.; Crugnola, M.; et al. Efficacy and safety of ruxolitinib in intermediate-1 IPSS risk myelofibrosis patients: Results from an independent study. Hematol. Oncol. 2018, 36, 285-290. [CrossRef] [PubMed]

5. Palandri, F.; Polverelli, N.; Catani, L.; Vianelli, N. Ruxolitinib-associated tuberculosis: A case of successful ruxolitinib rechallenge. Ann. Hematol. 2015, 94, 519-520. [CrossRef] [PubMed]

6. Palandri, F.; Polverelli, N.; Breccia, M.; Nicolino, B.; Vitolo, U.; Alimena, G.; Cavo, M.; Vianelli, N.; Benevolo, G. Safety and efficacy of ruxolitinib in myelofibrosis patients without splenomegaly. Br. J. Haematol. 2016, 174, 160-162. [CrossRef]

7. Palandri, F.; Palumbo, G.A.; Bonifacio, M.; Tiribelli, M.; Benevolo, G.; Martino, B.; Abruzzese, E.; D'Adda, M.; Polverelli, N.; Bergamaschi, M.; et al. Baseline factors associated with response to ruxolitinib: An independent study on 408 patients with myelofibrosis. Oncotarget 2017, 8, 79073-79086. [CrossRef]

8. Palandri, F.; Palumbo, G.A.; Bonifacio, M.; Breccia, M.; Latagliata, R.; Martino, B.; Polverelli, N.; Abruzzese, E.; Tiribelli, M.; Nicolosi, M.; et al. Durability of spleen response affects the outcome of ruxolitinib-treated patients with myelofibrosis: Results from a multicentre study on 284 patients. Leuk. Res. 2018, 74, 86-88. [CrossRef] 
9. McLornan, D.; Eikema, D.J.; Czerw, T.; Kroger, N.; Koster, L.; Reinhardt, H.C.; Angelucci, E.; Robin, M.; Bornhauser, M.; Passweg, J.; et al. Trends in allogeneic haematopoietic cell transplantation for myelofibrosis in Europe between 1995 and 2018: A CMWP of EBMT retrospective analysis. Bone Marrow Transplant. 2021, 56, 2160-2172. [CrossRef]

10. Cervantes, F.; Dupriez, B.; Pereira, A.; Passamonti, F.; Reilly, J.T.; Morra, E.; Vannucchi, A.M.; Mesa, R.A.; Demory, J.L.; Barosi, G.; et al. New prognostic scoring system for primary myelofibrosis based on a study of the International Working Group for Myelofibrosis Research and Treatment. Blood 2009, 113, 2895-2901. [CrossRef]

11. Passamonti, F.; Cervantes, F.; Vannucchi, A.M.; Morra, E.; Rumi, E.; Pereira, A.; Guglielmelli, P.; Pungolino, E.; Caramella, M.; Maffioli, M.; et al. A dynamic prognostic model to predict survival in primary myelofibrosis: A study by the IWG-MRT (International Working Group for Myeloproliferative Neoplasms Research and Treatment). Blood 2010, 115, 1703-1708. [CrossRef]

12. Gangat, N.; Caramazza, D.; Vaidya, R.; George, G.; Begna, K.; Schwager, S.; Van Dyke, D.; Hanson, C.; Wu, W.; Pardanani, A.; et al. DIPSS plus: A refined Dynamic International Prognostic Scoring System for primary myelofibrosis that incorporates prognostic information from karyotype, platelet count, and transfusion status. J. Clin. Oncol. Off. J. Am. Soc. Clin. Oncol. 2011, 29, 392-397. [CrossRef] [PubMed]

13. Hussein, K.; Pardanani, A.D.; Van Dyke, D.L.; Hanson, C.A.; Tefferi, A. International Prognostic Scoring System-independent cytogenetic risk categorization in primary myelofibrosis. Blood 2010, 115, 496-499. [CrossRef] [PubMed]

14. Kroger, N.M.; Deeg, J.H.; Olavarria, E.; Niederwieser, D.; Bacigalupo, A.; Barbui, T.; Rambaldi, A.; Mesa, R.; Tefferi, A.; Griesshammer, M.; et al. Indication and management of allogeneic stem cell transplantation in primary myelofibrosis: A consensus process by an EBMT/ELN international working group. Leukemia 2015, 29, 2126-2133. [CrossRef] [PubMed]

15. Kroger, N.; Giorgino, T.; Scott, B.L.; Ditschkowski, M.; Alchalby, H.; Cervantes, F.; Vannucchi, A.; Cazzola, M.; Morra, E.; Zabelina, T.; et al. Impact of allogeneic stem cell transplantation on survival of patients less than 65 years of age with primary myelofibrosis. Blood 2015, 125, 3347-3350. [CrossRef]

16. Gowin, K.; Ballen, K.; Ahn, K.W.; Hu, Z.H.; Ali, H.; Arcasoy, M.O.; Devlin, R.; Coakley, M.; Gerds, A.T.; Green, M.; et al. Survival following allogeneic transplant in patients with myelofibrosis. Blood Adv. 2020, 4, 1965-1973. [CrossRef]

17. Masarova, L.; Bose, P.; Daver, N.; Pemmaraju, N.; Newberry, K.J.; Manshouri, T.; Cortes, J.; Kantarjian, H.M.; Verstovsek, S. Patients with post-essential thrombocythemia and post-polycythemia vera differ from patients with primary myelofibrosis. Leuk. Res. 2017, 59, 110-116. [CrossRef]

18. Hernandez-Boluda, J.C.; Pereira, A.; Gomez, M.; Boque, C.; Ferrer-Marin, F.; Raya, J.M.; Garcia-Gutierrez, V.; Kerguelen, A.; Xicoy, B.; Barba, P.; et al. The International Prognostic Scoring System does not accurately discriminate different risk categories in patients with post-essential thrombocythemia and post-polycythemia vera myelofibrosis. Haematologica 2014,99 , e55-e57. [CrossRef]

19. Passamonti, F.; Giorgino, T.; Mora, B.; Guglielmelli, P.; Rumi, E.; Maffioli, M.; Rambaldi, A.; Caramella, M.; Komrokji, R.; Gotlib, J.; et al. A clinical-molecular prognostic model to predict survival in patients with post polycythemia vera and post essential thrombocythemia myelofibrosis. Leukemia 2017, 31, 2726-2731. [CrossRef]

20. Palandri, F.; Palumbo, G.A.; Iurlo, A.; Polverelli, N.; Benevolo, G.; Breccia, M.; Abruzzese, E.; Tiribelli, M.; Bonifacio, M.; Tieghi, A.; et al. Differences in presenting features, outcome and prognostic models in patients with primary myelofibrosis and post-polycythemia vera and/or post-essential thrombocythemia myelofibrosis treated with ruxolitinib. New perspective of the MYSEC-PM in a large multicenter study. Semin. Hematol. 2018, 55, 248-255. [CrossRef]

21. Gagelmann, N.; Eikema, D.J.; de Wreede, L.C.; Koster, L.; Wolschke, C.; Arnold, R.; Kanz, L.; McQuaker, G.; Marchand, T.; Socie, G.; et al. Comparison of Dynamic International Prognostic Scoring System and MYelofibrosis SECondary to PV and ET prognostic model for prediction of outcome in polycythemia vera and essential thrombocythemia myelofibrosis after allogeneic stem cell transplantation. Biol. Blood Marrow Transplant. J. Am. Soc. Blood Marrow Transplant. 2019, 25, e204-e208. [CrossRef]

22. Rumi, E.; Pietra, D.; Pascutto, C.; Guglielmelli, P.; Martinez-Trillos, A.; Casetti, I.; Colomer, D.; Pieri, L.; Pratcorona, M.; Rotunno, G.; et al. Clinical effect of driver mutations of JAK2, CALR, or MPL in primary myelofibrosis. Blood 2014, 124, 1062-1069. [CrossRef] [PubMed]

23. Tefferi, A.; Guglielmelli, P.; Lasho, T.L.; Rotunno, G.; Finke, C.; Mannarelli, C.; Belachew, A.A.; Pancrazzi, A.; Wassie, E.A.; Ketterling, R.P.; et al. CALR and ASXL1 mutations-based molecular prognostication in primary myelofibrosis: An international study of 570 patients. Leukemia 2014, 28, 1494-1500. [CrossRef]

24. Guglielmelli, P.; Lasho, T.L.; Rotunno, G.; Score, J.; Mannarelli, C.; Pancrazzi, A.; Biamonte, F.; Pardanani, A.; Zoi, K.; Reiter, A.; et al. The number of prognostically detrimental mutations and prognosis in primary myelofibrosis: An international study of 797 patients. Leukemia 2014, 28, 1804-1810. [CrossRef] [PubMed]

25. Vannucchi, A.M.; Lasho, T.L.; Guglielmelli, P.; Biamonte, F.; Pardanani, A.; Pereira, A.; Finke, C.; Score, J.; Gangat, N.; Mannarelli, C.; et al. Mutations and prognosis in primary myelofibrosis. Leukemia 2013, 27, 1861-1869. [CrossRef] [PubMed]

26. Tefferi, A.; Finke, C.M.; Lasho, T.L.; Hanson, C.A.; Ketterling, R.P.; Gangat, N.; Pardanani, A. U2AF1 mutation types in primary myelofibrosis: Phenotypic and prognostic distinctions. Leukemia 2018, 32, 2274-2278. [CrossRef]

27. McLornan, D.P.; Yakoub-Agha, I.; Robin, M.; Chalandon, Y.; Harrison, C.N.; Kroger, N. State-of-the-art review: Allogeneic stem cell transplantation for myelofibrosis in 2019. Haematologica 2019, 104, 659-668. [CrossRef]

28. Tamari, R.; Rapaport, F.; Zhang, N.; McNamara, C.; Kuykendall, A.; Sallman, D.A.; Komrokji, R.; Arruda, A.; Najfeld, V.; Sandy, L.; et al. Impact of high-molecular-risk mutations on transplantation outcomes in patients with myelofibrosis. Biol. Blood Marrow Transplant. J. Am. Soc. Blood Marrow Transplant. 2019, 25, 1142-1151. [CrossRef] 
29. Tefferi, A.; Guglielmelli, P.; Lasho, T.L.; Gangat, N.; Ketterling, R.P.; Pardanani, A.; Vannucchi, A.M. MIPSS70+ version 2.0: Mutation and karyotype-enhanced International Prognostic Scoring System for primary myelofibrosis. J. Clin. Oncol. Off. J. Am. Soc. Clin. Oncol. 2018, 36, 1769-1770. [CrossRef]

30. Tefferi, A.; Guglielmelli, P.; Nicolosi, M.; Mannelli, F.; Mudireddy, M.; Bartalucci, N.; Finke, C.M.; Lasho, T.L.; Hanson, C.A.; Ketterling, R.P.; et al. GIPSS: Genetically inspired prognostic scoring system for primary myelofibrosis. Leukemia 2018, 32, 1631-1642. [CrossRef]

31. Tiribelli, M.; Palandri, F.; Sant'Antonio, E.; Breccia, M.; Bonifacio, M. The role of allogeneic stem-cell transplant in myelofibrosis in the era of JAK inhibitors: A case-based review. Bone Marrow Transplant. 2020, 55, 708-716. [CrossRef] [PubMed]

32. Artz, A.S.; Pollyea, D.A.; Kocherginsky, M.; Stock, W.; Rich, E.; Odenike, O.; Zimmerman, T.; Smith, S.; Godley, L.; Thirman, M.; et al. Performance status and comorbidity predict transplant-related mortality after allogeneic hematopoietic cell transplantation. Biol. Blood Marrow Transplant. J. Am. Soc. Blood Marrow Transplant. 2006, 12, 954-964. [CrossRef] [PubMed]

33. Sorror, M.L.; Maris, M.B.; Storb, R.; Baron, F.; Sandmaier, B.M.; Maloney, D.G.; Storer, B. Hematopoietic cell transplantation (HCT)-specific comorbidity index: A new tool for risk assessment before allogeneic HCT. Blood 2005, 106, 2912-2919. [CrossRef] [PubMed]

34. Raimondi, R.; Tosetto, A.; Oneto, R.; Cavazzina, R.; Rodeghiero, F.; Bacigalupo, A.; Fanin, R.; Rambaldi, A.; Bosi, A. Validation of the hematopoietic cell transplantation-specific comorbidity index: A prospective, multicenter GITMO study. Blood 2012, 120, 1327-1333. [CrossRef]

35. Sorror, M.L.; Logan, B.R.; Zhu, X.; Rizzo, J.D.; Cooke, K.R.; McCarthy, P.L.; Ho, V.T.; Horowitz, M.M.; Pasquini, M.C. Prospective validation of the predictive power of the hematopoietic cell transplantation comorbidity index: A center for international blood and marrow transplant research study. Biol. Blood Marrow Transplant. J. Am. Soc. Blood Marrow Transplant. 2015, 21, 1479-1487. [CrossRef]

36. Hernandez-Boluda, J.C.; Pereira, A.; Kroger, N.; Cornelissen, J.J.; Finke, J.; Beelen, D.; de Witte, M.; Wilson, K.; Platzbecker, U.; Sengeloev, H.; et al. Allogeneic hematopoietic cell transplantation in older myelofibrosis patients: A study of the chronic malignancies working party of EBMT and the Spanish Myelofibrosis Registry. Am. J. Hematol. 2021, 96, 1186-1194. [CrossRef]

37. Liu, J.J.; Extermann, M. Comprehensive geriatric assessment and its clinical impact in oncology. Clin. Geriatr. Med. 2012, 28, 19-31. [CrossRef]

38. Hegde, A.; Murthy, H.S. Frailty: The missing piece of the pre- hematopoietic cell transplantation assessment? Bone Marrow Transplant. 2018, 53, 3-10. [CrossRef]

39. Polverelli, N.; Tura, P.; Battipaglia, G.; Malagola, M.; Bernardi, S.; Gandolfi, L.; Zollner, T.; Zanaglio, C.; Farina, M.; Morello, E.; et al. Multidimensional geriatric assessment for elderly hematological patients ( $\geq 60$ years) submitted to allogeneic stem cell transplantation. A French-Italian 10-year experience on 228 patients. Bone Marrow Transplant. 2020, 55, 2224-2233. [CrossRef]

40. Gagelmann, N.; Ditschkowski, M.; Bogdanov, R.; Bredin, S.; Robin, M.; Cassinat, B.; Shahswar, R.; Thol, F.; Heuser, M.; Socie, G.; et al. Comprehensive clinical-molecular transplant scoring system for myelofibrosis undergoing stem cell transplantation. Blood 2019, 133, 2233-2242. [CrossRef]

41. Kroger, N.; Holler, E.; Kobbe, G.; Bornhauser, M.; Schwerdtfeger, R.; Baurmann, H.; Nagler, A.; Bethge, W.; Stelljes, M.; Uharek, L.; et al. Allogeneic stem cell transplantation after reduced-intensity conditioning in patients with myelofibrosis: A prospective, multicenter study of the Chronic Leukemia Working Party of the European Group for Blood and Marrow Transplantation. Blood 2009, 114, 5264-5270. [CrossRef]

42. Gupta, V.; Malone, A.K.; Hari, P.N.; Ahn, K.W.; Hu, Z.H.; Gale, R.P.; Ballen, K.K.; Hamadani, M.; Olavarria, E.; Gerds, A.T.; et al. Reduced-intensity hematopoietic cell transplantation for patients with primary myelofibrosis: A cohort analysis from the center for international blood and marrow transplant research. Biol. Blood Marrow Transplant. J. Am. Soc. Blood Marrow Transplant. 2014, 20, 89-97. [CrossRef]

43. Rondelli, D.; Goldberg, J.D.; Isola, L.; Price, L.S.; Shore, T.B.; Boyer, M.; Bacigalupo, A.; Rambaldi, A.; Scarano, M.; Klisovic, R.B.; et al. MPD-RC 101 prospective study of reduced-intensity allogeneic hematopoietic stem cell transplantation in patients with myelofibrosis. Blood 2014, 124, 1183-1191. [CrossRef]

44. Shanavas, M.; Popat, U.; Michaelis, L.C.; Fauble, V.; McLornan, D.; Klisovic, R.; Mascarenhas, J.; Tamari, R.; Arcasoy, M.O.; Davies, J.; et al. Outcomes of allogeneic hematopoietic cell transplantation in patients with myelofibrosis with prior exposure to janus kinase 1/2 inhibitors. Biol. Blood Marrow Transplant. J. Am. Soc. Blood Marrow Transplant. 2016, 22, 432-440. [CrossRef]

45. Bregante, S.; Dominietto, A.; Ghiso, A.; Raiola, A.M.; Gualandi, F.; Varaldo, R.; Di Grazia, C.; Lamparelli, T.; Luchetti, S.; Geroldi, S.; et al. Improved outcome of alternative donor transplantations in patients with myelofibrosis: From unrelated to haploidentical family donors. Biol. Blood Marrow Transplant. J. Am. Soc. Blood Marrow Transplant. 2016, 22, 324-329. [CrossRef]

46. Raj, K.; Eikema, D.J.; McLornan, D.P.; Olavarria, E.; Blok, H.J.; Bregante, S.; Ciceri, F.; Passweg, J.; Ljungman, P.; Schaap, N.; et al. Family mismatched allogeneic stem cell transplantation for myelofibrosis: Report from the Chronic Malignancies Working Party of European Society for Blood and MARROW transplantation. Biol. Blood Marrow Transplant. J. Am. Soc. Blood Marrow Transplant. 2019, 25, 522-528. [CrossRef]

47. Murata, M.; Takenaka, K.; Uchida, N.; Ozawa, Y.; Ohashi, K.; Kim, S.W.; Ikegame, K.; Kanda, Y.; Kobayashi, H.; Ishikawa, J.; et al. Comparison of outcomes of allogeneic transplantation for primary myelofibrosis among hematopoietic stem cell source groups. Biol. Blood Marrow Transplant. J. Am. Soc. Blood Marrow Transplant. 2019, 25, 1536-1543. [CrossRef] 
48. Robin, M.; Giannotti, F.; Deconinck, E.; Mohty, M.; Michallet, M.; Sanz, G.; Chevallier, P.; Cahn, J.Y.; Legrand, F.; Rovira, M.; et al. Unrelated cord blood transplantation for patients with primary or secondary myelofibrosis. Biol. Blood Marrow Transplant. J. Am. Soc. Blood Marrow Transplant. 2014, 20, 1841-1846. [CrossRef]

49. Robin, M.; Tabrizi, R.; Mohty, M.; Furst, S.; Michallet, M.; Bay, J.O.; Cahn, J.Y.; De Coninck, E.; Dhedin, N.; Bernard, M.; et al. Allogeneic haematopoietic stem cell transplantation for myelofibrosis: A report of the Societe Francaise de Greffe de Moelle et de Therapie Cellulaire (SFGM-TC). Br. J. Haematol. 2011, 152, 331-339. [CrossRef]

50. Ballen, K. Myelofibrosis: Let's go high! Bone Marrow Transplant. 2021, 56, 2864-2865. [CrossRef]

51. Czerw, T.; Iacobelli, S.; Malpassuti, V.; Koster, L.; Kroger, N.; Robin, M.; Maertens, J.; Chevallier, P.; Watz, E.; Poire, X.; et al. Impact of donor-derived CD34 + infused cell dose on outcomes of patients undergoing allo-HCT following reduced intensity regimen for myelofibrosis: A study from the Chronic Malignancies Working Party of the EBMT. Bone Marrow Transplant. 2021. [CrossRef]

52. Wang, Y.; Wu, D.P.; Liu, Q.F.; Xu, L.P.; Liu, K.Y.; Zhang, X.H.; Xu, Y.; Huang, F.; Huang, X.J. Donor and recipient age, gender and ABO incompatibility regardless of donor source: Validated criteria for donor selection for haematopoietic transplants. Leukemia 2018, 32, 492-498. [CrossRef]

53. Kerbauy, D.M.; Gooley, T.A.; Sale, G.E.; Flowers, M.E.; Doney, K.C.; Georges, G.E.; Greene, J.E.; Linenberger, M.; Petersdorf, E.; Sandmaier, B.M.; et al. Hematopoietic cell transplantation as curative therapy for idiopathic myelofibrosis, advanced polycythemia vera, and essential thrombocythemia. Biol. Blood Marrow Transplant. J. Am. Soc. Blood Marrow Transplant. 2007, 13, 355-365. [CrossRef]

54. Guardiola, P.; Anderson, J.E.; Bandini, G.; Cervantes, F.; Runde, V.; Arcese, W.; Bacigalupo, A.; Przepiorka, D.; O’Donnell, M.R.; Polchi, P.; et al. Allogeneic stem cell transplantation for agnogenic myeloid metaplasia: A European Group for Blood and Marrow Transplantation, Societe Francaise de Greffe de Moelle, Gruppo Italiano per il Trapianto del Midollo Osseo, and Fred Hutchinson Cancer Research Center collaborative study. Blood 1999, 93, 2831-2838.

55. Robin, M.; Porcher, R.; Wolschke, C.; Sicre de Fontbrune, F.; Alchalby, H.; Christopeit, M.; Cassinat, B.; Zabelina, T.; Peffault de Latour, R.; Ayuk, F.; et al. Outcome after transplantation according to reduced-intensity conditioning regimen in patients undergoing transplantation for myelofibrosis. Biol. Blood Marrow Transplant. J. Am. Soc. Blood Marrow Transplant. 2016, 22, 1206-1211. [CrossRef]

56. Patriarca, F.; Masciulli, A.; Bacigalupo, A.; Bregante, S.; Pavoni, C.; Finazzi, M.C.; Bosi, A.; Russo, D.; Narni, F.; Messina, G.; et al. Busulfan- or thiotepa-based conditioning in myelofibrosis: A phase II multicenter randomized study from the GITMO Group. Biol. Blood Marrow Transplant. J. Am. Soc. Blood Marrow Transplant. 2019, 25, 932-940. [CrossRef]

57. McLornan, D.; Szydlo, R.; Koster, L.; Chalandon, Y.; Robin, M.; Wolschke, C.; Beelen, D.; Socie, G.; Bornhauser, M.; Angelucci, E.; et al. Myeloablative and reduced-intensity conditioned allogeneic hematopoietic stem cell transplantation in myelofibrosis: A retrospective study by the Chronic Malignancies Working Party of the European Society for Blood and Marrow Transplantation. Biol. Blood Marrow Transplant. J. Am. Soc. Blood Marrow Transplant. 2019, 25, 2167-2171. [CrossRef]

58. Chiusolo, P.; Bregante, S.; Giammarco, S.; Lamparelli, T.; Casarino, L.; Dominietto, A.; Raiola, A.M.; Metafuni, E.; Di Grazia, C.; Gualandi, F.; et al. Full donor chimerism after allogeneic hematopoietic stem cells transplant for myelofibrosis: The role of the conditioning regimen. Am. J. Hematol. 2021, 96, 234-240. [CrossRef]

59. Battipaglia, G.; Mauff, K.; Wendel, L.; Angelucci, E.; Mohty, M.; Arcese, W.; Santarone, S.; Rubio, M.T.; Kroger, N.; Fox, M.L.; et al. Thiotepa-busulfan-fludarabine (TBF) conditioning regimen in patients undergoing allogeneic hematopoietic cell transplantation for myelofibrosis: An outcome analysis from the Chronic Malignancies Working Party of the EBMT. Bone Marrow Transplant. 2021, 56, 1593-1602. [CrossRef]

60. Memoli, M.; Paviglianiti, A.; Malard, F.; Battipaglia, G.; Brissot, E.; Mediavilla, C.; Bianchessi, A.; Banet, A.; Van de Wyngaert, Z.; Ledraa, T.; et al. Thiotepa-busulfan-fludarabine as a conditioning regimen for patients with myelofibrosis undergoing allogeneic hematopoietic transplantation: A single center experience. Leuk. Lymphoma 2021, 62, 419-427. [CrossRef]

61. Shouval, R.; Vega, Y.; Fein, J.A.; Danylesko, I.; Shem Tov, N.; Yerushalmi, R.; Sobas, M.; Czyz, A.; Nagler, A.; Shimoni, A. Allogeneic hematopoietic stem cell transplantation with fludarabine, busulfan, and thiotepa conditioning is associated with favorable outcomes in myelofibrosis. Bone Marrow Transplant. 2020, 55, 147-156. [CrossRef] [PubMed]

62. McLornan, D.P.; Hernandez-Boluda, J.C.; Czerw, T.; Cross, N.; Joachim Deeg, H.; Ditschkowski, M.; Moonim, M.T.; Polverelli, N.; Robin, M.; Aljurf, M.; et al. Allogeneic haematopoietic cell transplantation for myelofibrosis: Proposed definitions and management strategies for graft failure, poor graft function and relapse: Best practice recommendations of the EBMT Chronic Malignancies Working Party. Leukemia 2021, 35, 2445-2459. [CrossRef] [PubMed]

63. Dupriez, B.; Morel, P.; Demory, J.L.; Lai, J.L.; Simon, M.; Plantier, I.; Bauters, F. Prognostic factors in agnogenic myeloid metaplasia: A report on 195 cases with a new scoring system. Blood 1996, 88, 1013-1018. [CrossRef] [PubMed]

64. Visani, G.; Finelli, C.; Castelli, U.; Petti, M.C.; Ricci, P.; Vianelli, N.; Gianni, L.; Zuffa, E.; Aloe Spiriti, M.A.; Latagliata, R.; et al. Myelofibrosis with myeloid metaplasia: Clinical and haematological parameters predicting survival in a series of 133 patients. $\mathrm{Br}$. J. Haematol. 1990, 75, 4-9. [CrossRef] [PubMed]

65. Zimran, E.; Tripodi, J.; Rampal, R.; Rappoport, F.; Zirkiev, S.; Hoffman, R.; Najfeld, V. Genomic characterization of spleens in patients with myelofibrosis. Haematologica 2018, 103, e446-e449. [CrossRef]

66. Mesa, R.A.; Li, C.Y.; Schroeder, G.; Tefferi, A. Clinical correlates of splenic histopathology and splenic karyotype in myelofibrosis with myeloid metaplasia. Blood 2001, 97, 3665-3667. [CrossRef] 
67. Prakash, S.; Hoffman, R.; Barouk, S.; Wang, Y.L.; Knowles, D.M.; Orazi, A. Splenic extramedullary hematopoietic proliferation in Philadelphia chromosome-negative myeloproliferative neoplasms: Heterogeneous morphology and cytological composition. Mod. Pathol. Off. J. U. S. Can. Acad. Pathol. Inc. 2012, 25, 815-827. [CrossRef]

68. Li, Z.; Gooley, T.; Applebaum, F.R.; Deeg, H.J. Splenectomy and hemopoietic stem cell transplantation for myelofibrosis. Blood 2001, 97, 2180-2181. [CrossRef]

69. Polverelli, N.; Mauff, K.; Kroger, N.; Robin, M.; Beelen, D.; Beauvais, D.; Chevallier, P.; Mohty, M.; Passweg, J.; Rubio, M.T.; et al. Impact of spleen size and splenectomy on outcomes of allogeneic hematopoietic cell transplantation for myelofibrosis: A retrospective analysis by the chronic malignancies working party on behalf of European society for blood and marrow transplantation (EBMT). Am. J. Hematol. 2021, 96, 69-79. [CrossRef]

70. Bacigalupo, A.; Soraru, M.; Dominietto, A.; Pozzi, S.; Geroldi, S.; Van Lint, M.T.; Ibatici, A.; Raiola, A.M.; Frassoni, F.; De Stefano, F.; et al. Allogeneic hemopoietic SCT for patients with primary myelofibrosis: A predictive transplant score based on transfusion requirement, spleen size and donor type. Bone Marrow Transplant. 2010, 45, 458-463. [CrossRef]

71. Harrison, C.; Kiladjian, J.J.; Al-Ali, H.K.; Gisslinger, H.; Waltzman, R.; Stalbovskaya, V.; McQuitty, M.; Hunter, D.S.; Levy, R.; Knoops, L.; et al. JAK inhibition with ruxolitinib versus best available therapy for myelofibrosis. N. Engl. J. Med. 2012, 366, 787-798. [CrossRef] [PubMed]

72. Verstovsek, S.; Mesa, R.A.; Gotlib, J.; Levy, R.S.; Gupta, V.; DiPersio, J.F.; Catalano, J.V.; Deininger, M.; Miller, C.; Silver, R.T.; et al. A double-blind, placebo-controlled trial of ruxolitinib for myelofibrosis. N. Engl. J. Med. 2012, 366, 799-807. [CrossRef] [PubMed]

73. Polverelli, N.; Palumbo, G.A.; Binotto, G.; Abruzzese, E.; Benevolo, G.; Bergamaschi, M.; Tieghi, A.; Bonifacio, M.; Breccia, M.; Catani, L.; et al. Epidemiology, outcome, and risk factors for infectious complications in myelofibrosis patients receiving ruxolitinib: A multicenter study on 446 patients. Hematol. Oncol. 2018, 36, 561-569. [CrossRef]

74. Polverelli, N.; Elli, E.M.; Abruzzese, E.; Palumbo, G.A.; Benevolo, G.; Tiribelli, M.; Bonifacio, M.; Tieghi, A.; Caocci, G.; D’Adda, M.; et al. Second primary malignancy in myelofibrosis patients treated with ruxolitinib. Br. J. Haematol. 2021, 193, 356-368. [CrossRef] [PubMed]

75. Alchalby, H.; Yunus, D.R.; Zabelina, T.; Kobbe, G.; Holler, E.; Bornhauser, M.; Schwerdtfeger, R.; Bethge, W.; Kvasnicka, H.M.; Busche, G.; et al. Risk models predicting survival after reduced-intensity transplantation for myelofibrosis. Br. J. Haematol. 2012, 157, 75-85. [CrossRef] [PubMed]

76. Alchalby, H.; Yunus, D.R.; Zabelina, T.; Ayuk, F.; Kroger, N. Incidence and risk factors of poor graft function after allogeneic stem cell transplantation for myelofibrosis. Bone Marrow Transplant. 2016, 51, 1223-1227. [CrossRef]

77. Kroger, N.; Sbianchi, G.; Sirait, T.; Wolschke, C.; Beelen, D.; Passweg, J.; Robin, M.; Vrhovac, R.; Helbig, G.; Sockel, K.; et al. Impact of prior JAK-inhibitor therapy with ruxolitinib on outcome after allogeneic hematopoietic stem cell transplantation for myelofibrosis: A study of the CMWP of EBMT. Leukemia 2021, 35, 3551-3556. [CrossRef]

78. Jaekel, N.; Behre, G.; Behning, A.; Wickenhauser, C.; Lange, T.; Niederwieser, D.; Al-Ali, H.K. Allogeneic hematopoietic cell transplantation for myelofibrosis in patients pretreated with the JAK1 and JAK2 inhibitor ruxolitinib. Bone Marrow Transplant. 2014, 49, 179-184. [CrossRef]

79. Stubig, T.; Alchalby, H.; Ditschkowski, M.; Wolf, D.; Wulf, G.; Zabelina, T.; Wolschke, C.; Ayuk, F.; Kroger, N. JAK inhibition with ruxolitinib as pretreatment for allogeneic stem cell transplantation in primary or post-ET/PV myelofibrosis. Leukemia 2014, 28, 1736-1738. [CrossRef]

80. Robin, M.; Francois, S.; Huynh, A.; Cassinat, B.; Bay, J.O.; Cornillon, J.; Rolland, V.; Charbonnier, A.; Michallet, M.; Boyer, F.; et al. Ruxolitinib before allogeneic hematopoietic stem cell transplantation (HSCT) in patients with myelofibrosis: A preliminary descriptive report of the JAK ALLO Study, a phase II trial sponsored by Goelams-FIM in collaboration with the Sfgmtc. Blood 2013, 122, 306. [CrossRef]

81. Shiratori, S.; Tateno, T.; Ito, S.; Tsutsumi, Y.; Teshima, T. Evaluation of short-term Ruxolitinib tapering strategy before allogeneic stem cell transplantation for primary myelofibrosis through the transition of serum cytokines and growth factors. Transpl. Direct 2016, 2, e95. [CrossRef] [PubMed]

82. Salit, R.B.; Scott, B.L.; Stevens, E.A.; Baker, K.K.; Gooley, T.A.; Deeg, H.J. Pre-hematopoietic cell transplant Ruxolitinib in patients with primary and secondary myelofibrosis. Bone Marrow Transplant. 2020, 55, 70-76. [CrossRef]

83. Morozova, E.V.; Barabanshikova, M.V.; Moiseev, I.S.; Shakirova, A.I.; Barhatov, I.M.; Ushal, I.E.; Rodionov, G.G.; Moiseev, S.I.; Surkova, E.A.; Lapin, S.V.; et al. A prospective pilot study of graft-versus-host disease prophylaxis with post-transplantation Cyclophosphamide and Ruxolitinib in patients with myelofibrosis. Acta Haematol. 2021, 144, 158-165. [CrossRef]

84. Kroger, N.; Shahnaz Syed Abd Kadir, S.; Zabelina, T.; Badbaran, A.; Christopeit, M.; Ayuk, F.; Wolschke, C. Peritransplantation Ruxolitinib prevents acute graft-versus-host disease in patients with myelofibrosis undergoing allogenic stem cell transplantation. Biol. Blood Marrow Transplant. J. Am. Soc. Blood Marrow Transplant. 2018, 24, 2152-2156. [CrossRef]

85. Zeiser, R.; von Bubnoff, N.; Butler, J.; Mohty, M.; Niederwieser, D.; Or, R.; Szer, J.; Wagner, E.M.; Zuckerman, T.; Mahuzier, B.; et al. Ruxolitinib for glucocorticoid-refractory acute graft-versus-host disease. N. Engl. J. Med. 2020, 382, 1800-1810. [CrossRef]

86. Zeiser, R.; Polverelli, N.; Ram, R.; Hashmi, S.K.; Chakraverty, R.; Middeke, J.M.; Musso, M.; Giebel, S.; Uzay, A.; Langmuir, P.; et al. Ruxolitinib for glucocorticoid-refractory chronic graft-versus-host disease. N. Engl. J. Med. 2021, 385, 228-238. [CrossRef]

87. Shahnaz Syed Abd Kadir, S.; Christopeit, M.; Wulf, G.; Wagner, E.; Bornhauser, M.; Schroeder, T.; Crysandt, M.; Mayer, K.; Jonas, J.; Stelljes, M.; et al. Impact of Ruxolitinib pretreatment on outcomes after allogeneic stem cell transplantation in patients with myelofibrosis. Eur. J. Haematol. 2018, 101, 305-317. [CrossRef] 
88. Gupta, V.; Kosiorek, H.E.; Mead, A.; Klisovic, R.B.; Galvin, J.P.; Berenzon, D.; Yacoub, A.; Viswabandya, A.; Mesa, R.A.; Goldberg, J.; et al. Ruxolitinib therapy followed by reduced-intensity conditioning for hematopoietic cell transplantation for myelofibrosis: Myeloproliferative Disorders Research Consortium 114 Study. Biol. Blood Marrow Transplant. J. Am. Soc. Blood Marrow Transplant. 2019, 25, 256-264. [CrossRef]

89. Ali, H.; Tsai, N.C.; Synold, T.; Mokhtari, S.; Tsai, W.; Palmer, J.; Stiller, T.; Salhotra, A.; Rahmanuddin, S.; Pullarkat, V.A.; et al. Peritransplant Ruxolitinib administration is safe and effective in patients with myelofibrosis: A pilot open-label study. Blood Adv. 2021. [CrossRef]

90. Robin, M.; Porcher, R.; Orvain, C.; Bay, J.O.; Barraco, F.; Huynh, A.; Charbonnier, A.; Forcade, E.; Chantepie, S.; Bulabois, C.; et al Ruxolitinib before allogeneic hematopoietic transplantation in patients with myelofibrosis on behalf SFGM-TC and FIM groups. Bone Marrow Transplant. 2021, 56, 1888-1899. [CrossRef]

91. Harrison, C.N.; Schaap, N.; Vannucchi, A.M.; Kiladjian, J.J.; Tiu, R.V.; Zachee, P.; Jourdan, E.; Winton, E.; Silver, R.T.; Schouten, H.C.; et al. Janus kinase-2 inhibitor fedratinib in patients with myelofibrosis previously treated with ruxolitinib (JAKARTA-2): A single-arm, open-label, non-randomised, phase 2, multicentre study. Lancet Haematol. 2017, 4, e317-e324. [CrossRef]

92. Pardanani, A.; Harrison, C.; Cortes, J.E.; Cervantes, F.; Mesa, R.A.; Milligan, D.; Masszi, T.; Mishchenko, E.; Jourdan, E.; Vannucchi, A.M.; et al. Safety and efficacy of Fedratinib in patients with primary or secondary myelofibrosis: A randomized clinical trial. JAMA Oncol. 2015, 1, 643-651. [CrossRef]

93. Harrison, C.N.; Schaap, N.; Vannucchi, A.M.; Kiladjian, J.J.; Jourdan, E.; Silver, R.T.; Schouten, H.C.; Passamonti, F.; Zweegman, S.; Talpaz, M.; et al. Fedratinib in patients with myelofibrosis previously treated with ruxolitinib: An updated analysis of the JAKARTA2 study using stringent criteria for Ruxolitinib failure. Am. J. Hematol. 2020, 95, 594-603. [CrossRef] [PubMed]

94. Harrison, C.N.; Vannucchi, A.M.; Platzbecker, U.; Cervantes, F.; Gupta, V.; Lavie, D.; Passamonti, F.; Winton, E.F.; Dong, H.; Kawashima, J.; et al. Momelotinib versus best available therapy in patients with myelofibrosis previously treated with Ruxolitinib (SIMPLIFY 2): A randomised, open-label, phase 3 trial. Lancet Haematol. 2018, 5, e73-e81. [CrossRef]

95. Mascarenhas, J.; Hoffman, R.; Talpaz, M.; Gerds, A.T.; Stein, B.; Gupta, V.; Szoke, A.; Drummond, M.; Pristupa, A.; Granston, T.; et al. Pacritinib vs best available therapy, including Ruxolitinib, in patients with myelofibrosis: A randomized clinical trial. JAMA Oncol. 2018, 4, 652-659. [CrossRef]

96. Venugopal, S.; Mascarenhas, J. Current clinical investigations in myelofibrosis. Hematol. Oncol. Clin. N. Am. 2021, 35, 353-373. [CrossRef]

97. Robin, M.; Zine, M.; Chevret, S.; Meignin, V.; Munoz-Bongrand, N.; Moatti, H.; Xhaard, A.; Sicre de Fontbrune, F.; Peffault de Latour, R.; Sarfati, E.; et al. The impact of splenectomy in myelofibrosis patients before allogeneic hematopoietic stem cell transplantation. Biol. Blood Marrow Transplant. J. Am. Soc. Blood Marrow Transplant. 2017, 23, 958-964. [CrossRef]

98. Mesa, R.A.; Nagorney, D.S.; Schwager, S.; Allred, J.; Tefferi, A. Palliative goals, patient selection, and perioperative platelet management: Outcomes and lessons from 3 decades of splenectomy for myelofibrosis with myeloid metaplasia at the Mayo Clinic. Cancer 2006, 107, 361-370. [CrossRef]

99. Lee, G.M. Preventing infections in children and adults with asplenia. In Hematology 2014, the American Society of Hematology Education Program Book; ASH Publications: Washington, DC, USA, 2020; Volume 2020, pp. 328-335. [CrossRef]

100. Barosi, G.; Ambrosetti, A.; Centra, A.; Falcone, A.; Finelli, C.; Foa, P.; Grossi, A.; Guarnone, R.; Rupoli, S.; Luciano, L.; et al. Splenectomy and risk of blast transformation in myelofibrosis with myeloid metaplasia. Blood 1998, 91, 3630-3636.

101. Bossard, J.B.; Beuscart, J.B.; Robin, M.; Mohty, M.; Barraco, F.; Chevallier, P.; Marchand, T.; Rubio, M.T.; Charbonnier, A.; Blaise, D.; et al. Splenectomy before allogeneic hematopoietic cell transplantation for myelofibrosis: A French nationwide study. Am. J. Hematol. 2020, 96, 80-88. [CrossRef]

102. Elliott, M.A.; Tefferi, A. Splenic irradiation in myelofibrosis with myeloid metaplasia: A review. Blood Rev. 1999, 13, 163-170. [CrossRef] [PubMed]

103. Vyas, O.H.; Kaul, E.; Rosemberg, A.S.; Shah, G.L.; Shah, U.A.; Comenzo, R.L.; Shih-Hui Kao, G.; Evens, A.M.; Smith, H.; Klein, A.K.; et al. Splenic irradiation and a reduced-intensity conditioning regimen prior to allogeneic stem-cell transplantation for myelofibrosis. Blood 2014, 124, 3170. [CrossRef]

104. Huang, J.; Li, C.Y.; Mesa, R.A.; Wu, W.; Hanson, C.A.; Pardanani, A.; Tefferi, A. Risk factors for leukemic transformation in patients with primary myelofibrosis. Cancer 2008, 112, 2726-2732. [CrossRef] [PubMed]

105. Polverelli, N.; Catani, L.; Vianelli, N.; Baccarani, M.; Cavo, M.; Palandri, F. Ruxolitinib- but not fedratinib-induced extreme thrombocytosis: The combination therapy with hydroxyurea and ruxolitinib is effective in reducing platelet count and splenomegaly/constitutional symptoms. Ann. Hematol. 2015, 94, 1585-1587. [CrossRef] [PubMed]

106. Angelucci, E.; Pilo, F. Management of iron overload before, during, and after hematopoietic stem cell transplantation for thalassemia major. Ann. N. Y. Acad. Sci. 2016, 1368, 115-121. [CrossRef]

107. Isidori, A.; Loscocco, F.; Visani, G.; Chiarucci, M.; Musto, P.; Kubasch, A.S.; Platzbecker, U.; Vinchi, F. Iron toxicity and chelation therapy in hematopoietic stem cell transplant. Transpl. Cell Ther. 2021, 27, 371-379. [CrossRef]

108. Atilla, E.; Toprak, S.K.; Demirer, T. Current review of iron overload and related complications in hematopoietic stem cell transplantation. Turk. J. Haematol. Off. J. Turk. Soc. Haematol. 2017, 34, 1-9. [CrossRef]

109. Zhang, Y.; Zhai, W.; Zhao, M.; Li, D.; Chai, X.; Cao, X.; Meng, J.; Chen, J.; Xiao, X.; Li, Q.; et al. Effects of iron overload on the bone marrow microenvironment in mice. PLoS ONE 2015, 10, e0120219. [CrossRef] 
110. Chai, X.; Li, D.; Cao, X.; Zhang, Y.; Mu, J.; Lu, W.; Xiao, X.; Li, C.; Meng, J.; Chen, J.; et al. ROS-mediated iron overload injures the hematopoiesis of bone marrow by damaging hematopoietic stem/progenitor cells in mice. Sci. Rep. 2015, 5, 10181. [CrossRef]

111. Okabe, H.; Suzuki, T.; Uehara, E.; Ueda, M.; Nagai, T.; Ozawa, K. The bone marrow hematopoietic microenvironment is impaired in iron-overloaded mice. Eur. J. Haematol. 2014, 93, 118-128. [CrossRef]

112. Hernandez-Boluda, J.C.; Martinez-Trillos, A.; Garcia-Gutierrez, V.; Ferrer-Marin, F.; Xicoy, B.; Alvarez-Larran, A.; Kerguelen, A.; Barba, P.; Gomez, M.; Herrera, J.C.; et al. Long-term results of prednisone treatment for the anemia of myelofibrosis. Leuk. Lymphoma 2016, 57, 120-124. [CrossRef] [PubMed]

113. Shimoda, K.; Shide, K.; Kamezaki, K.; Okamura, T.; Harada, N.; Kinukawa, N.; Ohyashiki, K.; Niho, Y.; Mizoguchi, H.; Omine, M.; et al. The effect of anabolic steroids on anemia in myelofibrosis with myeloid metaplasia: Retrospective analysis of 39 patients in Japan. Int. J. Hematol. 2007, 85, 338-343. [CrossRef] [PubMed]

114. Cervantes, F.; Alvarez-Larran, A.; Domingo, A.; Arellano-Rodrigo, E.; Montserrat, E. Efficacy and tolerability of danazol as a treatment for the anaemia of myelofibrosis with myeloid metaplasia: Long-term results in 30 patients. Br. J. Haematol. 2005, 129, 771-775. [CrossRef] [PubMed]

115. Mesa, R.A.; Tefferi, A.; Li, C.Y.; Steensma, D.P. Hematologic and cytogenetic response to lenalidomide monotherapy in acute myeloid leukemia arising from JAK2(V617F) positive, del(5)(q13q33) myelodysplastic syndrome. Leukemia 2006, 20, 2063-2064. [CrossRef] [PubMed]

116. Weinkove, R.; Reilly, J.T.; McMullin, M.F.; Curtin, N.J.; Radia, D.; Harrison, C.N. Low-dose thalidomide in myelofibrosis. Haematologica 2008, 93, 1100-1101. [CrossRef] [PubMed]

117. Quintas-Cardama, A.; Kantarjian, H.M.; Manshouri, T.; Thomas, D.; Cortes, J.; Ravandi, F.; Garcia-Manero, G.; Ferrajoli, A.; Bueso-Ramos, C.; Verstovsek, S. Lenalidomide plus prednisone results in durable clinical, histopathologic, and molecular responses in patients with myelofibrosis. J. Clin. Oncol. Off. J. Am. Soc. Clin. Oncol. 2009, 27, 4760-4766. [CrossRef]

118. Mesa, R.A.; Steensma, D.P.; Pardanani, A.; Li, C.Y.; Elliott, M.; Kaufmann, S.H.; Wiseman, G.; Gray, L.A.; Schroeder, G.; Reeder, T.; et al. A phase 2 trial of combination low-dose thalidomide and prednisone for the treatment of myelofibrosis with myeloid metaplasia. Blood 2003, 101, 2534-2541. [CrossRef]

119. Marchetti, M.; Barosi, G.; Balestri, F.; Viarengo, G.; Gentili, S.; Barulli, S.; Demory, J.L.; Ilariucci, F.; Volpe, A.; Bordessoule, D.; et al. Low-dose thalidomide ameliorates cytopenias and splenomegaly in myelofibrosis with myeloid metaplasia: A phase II trial. J. Clin. Oncol. Off. J. Am. Soc. Clin. Oncol. 2004, 22, 424-431. [CrossRef]

120. Cervantes, F.; Alvarez-Larran, A.; Hernandez-Boluda, J.C.; Sureda, A.; Torrebadell, M.; Montserrat, E. Erythropoietin treatment of the anaemia of myelofibrosis with myeloid metaplasia: Results in 20 patients and review of the literature. Br. J. Haematol. 2004, 127, 399-403. [CrossRef]

121. Huang, J.; Tefferi, A. Erythropoiesis stimulating agents have limited therapeutic activity in transfusion-dependent patients with primary myelofibrosis regardless of serum erythropoietin level. Eur. J. Haematol. 2009, 83, 154-155. [CrossRef]

122. Hernandez-Boluda, J.C.; Correa, J.G.; Garcia-Delgado, R.; Martinez-Lopez, J.; Alvarez-Larran, A.; Fox, M.L.; Garcia-Gutierrez, V.; Perez-Encinas, M.; Ferrer-Marin, F.; Mata-Vazquez, M.I.; et al. Predictive factors for anemia response to erythropoiesis-stimulating agents in myelofibrosis. Eur. J. Haematol. 2017, 98, 407-414. [CrossRef]

123. Crisa, E.; Cilloni, D.; Elli, E.M.; Martinelli, V.; Palumbo, G.A.; Pugliese, N.; Beggiato, E.; Frairia, C.; Cerrano, M.; Lanzarone, G.; et al. The use of erythropoiesis-stimulating agents is safe and effective in the management of anaemia in myelofibrosis patients treated with ruxolitinib. Br. J. Haematol. 2018, 182, 701-704. [CrossRef]

124. Palumbo, G.A.; Galimberti, S.; Barcellini, W.; Cilloni, D.; Di Renzo, N.; Elli, E.M.; Finelli, C.; Maurillo, L.; Ricco, A.; Musto, P.; et al. From biology to clinical practice: Iron chelation therapy with deferasirox. Front. Oncol. 2021, 11, 752192. [CrossRef] [PubMed]

125. Latagliata, R.; Montagna, C.; Porrini, R.; Di Veroli, A.; Leonetti, S.C.; Niscola, P.; Ciccone, F.; Spadea, A.; Breccia, M.; Maurillo, L.; et al. Chelation efficacy and erythroid response during deferasirox treatment in patients with myeloproliferative neoplasms in fibrotic phase. Eur. J. Haematol. 2016, 96, 643-649. [CrossRef] [PubMed]

126. Elli, E.M.; Iurlo, A.; Aroldi, A.; Caramella, M.; Malato, S.; Casartelli, E.; Maffioli, M.; Gardellini, A.; Carraro, M.C.; D'Adda, M.; et al. Deferasirox in the management of iron-overload in patients with myelofibrosis: A multicentre study from the Rete Ematologica Lombarda (IRON-M study). Br. J. Haematol. 2019, 186, e123-e126. [CrossRef]

127. Tanaka, H.; Espinoza, J.L.; Fujiwara, R.; Rai, S.; Morita, Y.; Ashida, T.; Kanakura, Y.; Matsumura, I. Excessive reactive iron impairs hematopoiesis by affecting both immature hematopoietic cells and stromal cells. Cells 2019, 8, 226. [CrossRef]

128. Palandri, F.; Breccia, M.; Bonifacio, M.; Polverelli, N.; Elli, E.M.; Benevolo, G.; Tiribelli, M.; Abruzzese, E.; Iurlo, A.; Heidel, F.H.; et al. Life after ruxolitinib: Reasons for discontinuation, impact of disease phase, and outcomes in 218 patients with myelofibrosis. Cancer 2020, 126, 1243-1252. [CrossRef] [PubMed]

129. Ortmann, C.A.; Kent, D.G.; Nangalia, J.; Silber, Y.; Wedge, D.C.; Grinfeld, J.; Baxter, E.J.; Massie, C.E.; Papaemmanuil, E.; Menon, S.; et al. Effect of mutation order on myeloproliferative neoplasms. N. Engl. J. Med. 2015, 372, 601-612. [CrossRef] [PubMed]

130. Gagelmann, N.; Wolschke, C.; Salit, R.B.; Schroeder, T.; Ditschkowski, M.; Panagiota, V.; Cassinat, B.; Thol, F.; Badbaran, A.; Robin, M.; et al. Reduced intensity hematopoietic stem cell transplantation for myelofibrosis in accelerated-phase. Blood Adv. 2022. [CrossRef]

131. Gupta, V.; Kim, S.; Hu, Z.H.; Liu, Y.; Aljurf, M.; Bacher, U.; Beitinjaneh, A.; Cahn, J.Y.; Cerny, J.; Copelan, E.; et al. Comparison of outcomes of HCT in blast phase of BCR-ABL1- MPN with de novo AML and with AML following MDS. Blood Adv. 2020, 4, 4748-4757. [CrossRef] 